TEMPERATURE AFFECTS ADHESION

OF THE ACORN BARNACLE, BALANUS AMPHITRITE

\author{
A Thesis \\ Presented to the Faculty of \\ California Polytechnic State University, \\ San Luis Obispo
}

\author{
In Partial Fulfillment \\ of the Requirements for the Degree \\ Master of Science in Biological Sciences
}

by

Laurel A. Johnston

March, 2010 
(C) 2009

Laurel Johnston 


\section{ALL RIGHTS RESERVED}

COMMITTEE MEMBERSHIP

TITLE: TEMPERATURE AFFECTS ADHESION OF THE ACORN BARNACLE, BALANUS AMPHITRITE
AUTHOR:
Laurel A. Johnston

DATE SUBMITTED: $\quad$ February 2010

COMMITTEE CHAIR: Dean E. Wendt, Ph. D

COMMITTEE MEMBER: Lars Tomanek, Ph. D

COMMITTEE MEMBER: Royden Nakamura, Ph. D 


\title{
ABSTRACT \\ TEMPERATURE AFFECTS ADHESION \\ OF THE BARNACLE (BALANUS AMPHITRITE)
}

\author{
Laurel A. Johnston
}

Biofouling is the accumulation of sessile marine organisms, such as algae, tube worms and barnacles on man-made substrata and has negative economic and ecological implications. Ship hulls are readily fouled, which significantly increases drag while decreasing ship fuel efficiency when moving through water. Fouled hulls have also become important vectors of invasive species. These problems are minimized when hulls are painted with a toxic anti-fouling or non-toxic foul-release coating. Due to recent restrictions of anti-fouling paint use, research and development of non-toxic alternatives has increased.

Novel hull coating efficiency is often quantified by the critical removal stress value of barnacles from the coating. Barnacle adhesive cement protein content is thought to be responsible for barnacles' incredible ability to adhere underwater. The expression level and type of adhesive proteins has eluded scientists due to their extreme insolubility within cured barnacle cement. Identification of these proteins may provide insight to the adhesion of fouling species and aid coating development.

Barnacles are a cosmopolitan organism, able to withstand a wide range of environmental conditions, yet foul-release coating research had not previously incorporated environmental factors as variables in determining coating performance. Temperature is known to affect protein structure and function and is also a formative 
factor of barnacle larvae survival and development. Even so, the interaction between temperature and barnacle adhesion to has not previously been explored. We examined the effect of temperature on barnacle adhesion to foul-release coatings. After observing differences in critical removal stress due to temperature, we attempted to attribute these differences to specific proteins within the adhesive using 2D SDS PAGE. Gel image analysis determined that there were significant differences in cement protein expression between barnacles raised within different temperatures. Preliminary protein identification with Mass Spectronomy (MALDI TOF/TOF) was performed, however further research and a larger barnacle genomic database is needed to elucidate barnacle cement protein sequences. 


\section{ACKNOWLEDGEMENTS}

I thank Dean Wendt for his talent and passion for Marine Science, Royden Nakamura for his unlimited support and good nature, Lars Tomanek for spurring me to pursue an integrated approach to science, and Eric Holm for his dedication to fouling research and fantastic sense of humor. Many heartfelt thanks to Lenora Brewer, Beatriz Orehuela, Jake Valenzuela, Lauren Hitt, Dan Rittschoff, Gary Dickinson, Rowan Trebilco, Helen Dickson and all members of the DEW, Tomanek and Adams labs. And to my parents, Brian and Judy Johnston, who have so lovingly supported all my endeavors, thank you.

For the barnacles who gave their lives in the name of science.

This research was made possible by the financial support of the Office of Naval Research and the Naval Research Enterprise Intern Program 


\section{TABLE OF CONTENTS}

List of Figures..........................................................viii

\section{CHAPTER}

1.0 Background..............................................................1

1.1 Biofouling.........................................................1

1.1.1 Marine Fouling: Definition and Implications.................

1.1.2 Barnacles: Intriguing underwater adhesion....................2

1.1.3 Anti-fouling coatings: A problematic solution...................4

1.1.4 Foul-release coatings: Non-toxic alternatives..................5

1.2 Environmental Influences on Barnacle Adhesion.....................5

1.2.1 Foul-release coatings at work............................5

1.2.2 Barnacles in a Dynamic Environment........................ 7

1.3 Barnacle Cement...............................................9

1.3.1 A sticky situation........................................... 9

1.3.2 Determining cement protein composition..................11

1.3.3 Hypothesis............................................13

2.0 Temperature effects on Critical Removal Stress.......................15

2.1 Introduction...................................................15

2.2 Materials and Methods.........................................16

2.2.1 Experiments conducted at CPSLO......................... 17

2.2.1.1 Silicon substrate............................17

2.2.1.2 Larval settlement and barnacle rearing...........17

2.2.1.3 Shear removal...............................18

2.2.1.4 Critical removal stress analysis...................18

2.2.1.5 Abnormal cement measurement...................19

2.2.2 Experiments conducted at DUML..........................20

2.2.2.1 Expanded research design.....................20

2.2.2.2 Silicon substrata.............................20

2.2.2.3 Larval settlement and barnacle rearing...........20

2.2.2.4 Critical removal stress analysis.................21

2.3 Results........................................................22

2.3.1 Growth............................................. 22

2.3.2 Critical removal stress....................................24

2.3.3 Family groups..........................................27

2.3.4 Abnormal cement ratio...................................29

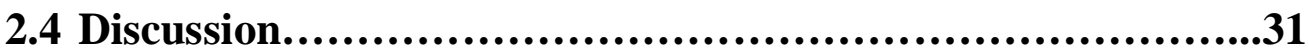

2.4.1 Temperature

2.4.2 Genetic relationship and CRS .......................... 32 


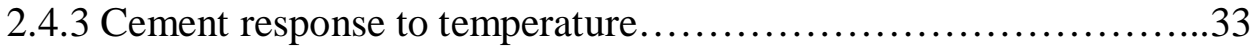

2.4.4 Abnormal cement production................................... 34

2.4.5 Ecophenotypic response to temperature...........................35

2.4.6 Coating/temperature interaction...............................36

3.0 Temperature Effects on Barnacle Cement Proteins..........................37

3.1 Introduction...........................................................37

3.2 Materials and Methods....................................................39

3.2.1 Larval settlement and barnacle rearing........................39

3.2.2 Cement collection...............................................39

3.2.3 Protein purification and concentration analysis.................41

3.2.4 Isoelectric focusing and protein separation.......................41

3.2.5 Gel imaging and analysis.................................42

3.2.6 Spot picking and preparation.....................................42

3.2.7 MASS Spectrometry.....................................45

3.3 Results..............................................................45

3.3.1 Protein concentration in cement............................45

3.3.2 Gel image analysis.......................................46

3.3.3 MASS Spectrometry analysis................................48

3.4 Discussion.........................................................49

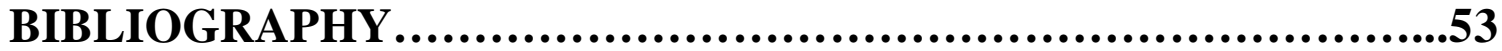




\section{List of Figures}

1 Barnacle Life Cycle..........................................................4

2 Slope of Relative Adhesion..................................................7

3 Biannual Average North Carolina Water Temperatures........................9

4 Barnacle Cement Production.................................................10

5 Barnacle Basal Plate Morphologies........................................12

6 Average Growth at CPSLO...............................................22

7 Average Growth at DUML.................................................23

8 Average CRS at CPSLO ................................................25

9 Differences in CRS between Coating........................................25

10 Average CRS on T2 at DUML .............................................26

11 CRS and Basal Area......................................................27

12 Family Trends in CRS: T2.............................................28

13 Family Trends in CRS: Veridian...................................................28

14 Abnormal Cement Frequency at DUML.........................................30

15 Abnormal Cement Frequency at CPSLO.......................................30

16 Abnormal Cement Differences between Substrata............................31

17 Liquid Cement Collection....................................................39

18 Protein Spots for Mass Spec.......................................................43

19 2D Image of Protein Expression..............................................47

20 Hierarchical Tree...................................................................48 


\subsection{Background}

\subsection{Biofouling background}

\subsubsection{Marine fouling: Definition and implications}

Materials submerged in seawater experience a series of physical, chemical and biological events which results in the formation of a complex layer of attached organisms known as biofouling (Abarzua and Jakubowski 1995). Recruitment of marine organisms is a natural and important aspect of intertidal systems, yet it can be problematic when it occurs on man-made substrata. Biofouling accumulation results in major ecological and economic costs when the substrate becomes corroded, blocked or damaged while in use (Callow and Callow 2002; Schultz et al. 2003; Holm et al. 2004a). Biofouling is also an important vector of invasive species (Brancato and Maclellan 1999; Godwin et al. 2004; Mineur et al. 2008; Piola and Johnston 2008; Piola et al. 2009).

Biofouling is divided into two categories based on fouling type (Callow and Callow 2002). Microfouling is the initial layer consisting of protozoa, diatoms, and microalgal spores, whereas macrofouling appears on submerged substrata after two to three weeks and consists of tunicates, bryozoans, mussels, barnacles, and polychaetes. The most costly problems usually begin with heavy accumulation of macrofouling though drag can significantly increase due to a seemingly thin layer of microfouling. Shultz (2007) predicted an increase in total drag of $\sim 11 \%$ due to an initial slime layer and up to $89 \%$ when heavily fouled with a calcareous layer on a mid-size naval ship traveling at cruising speeds ( $\sim 15$ knots). 
The Navy alone spends over $\$ 500$ million annually on maintenance, extra fuel costs and research due to biofouling (Khandeparker et al. 2002). Because biofouling is such a significant problem, considerable research has been done on the adhesion abilities of hard fouling organisms, particularly barnacles and mussels (Callow and Callow 2002). Barnacle adhesion has been well documented (Bourget 1980; Crisp and Bourget 1985; Holm 1990; Konya and Miki 1994; Holm et al. 2000; Swain et al. 2000; Callow and Callow 2002; Berglin et al. 2003; Dahlstrom et al. 2004; Holm et al. 2004b; Holm et al. 2005; Kavanagh et al. 2005; Wendt et al. 2006; Wiegemann et al. 2006; Conlan et al. 2008; Ramsay et al. 2008) making them an excellent model organism for our current study.

\subsubsection{Barnacles: Intriguing underwater adhesion}

Acorn barnacles are crustaceans in the Order Sessilia (Lamark, 1818) and the Family of Balanidae (Leach 1817). Their shell, which protects the soft exoskeleton, is rigid and in a volcanic cone shape. Around 1,220 species of barnacles are currently known and are widely dispersed in oceans around the world. They can be found in the upper to low intertidal and in extreme environments such as in sea ice on the north Atlantic coast (Pineda et al. 2005) or deep waters near hydrothermal vents (Tunnicliffe 1991). Adults are simultaneous hermaphrodites and fertilization occurs internally. Larval development of barnacles includes six nauplii instar stages and a final nonfeeding cyprid stage before its first metamorphosis (Figure 1) (Pechenik et al. 1998). Cyprid locomotion, exploration and settlement has been well documented (Knight-Jones 1953; Crisp 1983; Yule and Crisp 1983; Crisp 1985; Crisp et al. 1985; Crisp 1990; 
Mullineaux and Butman 1991; Glenner and Hoeg 1993; Konya and Miki 1994; Miron et al. 2000; Dahlstrom et al. 2004) use their antennae to "walk" along a substrate until a suitable location is found to settle. Faimali et al. (2004) found that barnacle cyprids may perceive signals about the substratum surface or its biofilm, which plays a role in their settlement preference. Studies by Hills et al. (1998) and Kawahara et al. (1999) are examples of how cyprids respond to chemical cues (Clare et al. 1995) and the hormone anthropodin from adult barnacles(Crisp 1990). Barnacles produce a pheromone like substance and neurotransmitters such as serotonin and dopamine, which are thought to act as settlement inducers(Crisp 1985; Clare and Matsumura 2000). They also show partiality to physical cues from the surface of a substrate (Roberts et al. 1991) and can distinguish between habitats based on the community structure of initially settled bacteria (biofilm) (Maki et al. 1992; Lau et al. 2005). Video analysis showed that cyprids can determine the timing of their settlement depending on cues from their environment and can actually begin settling within a matter of seconds after finding a suitable location (Mullineaux and Butman 1991). 


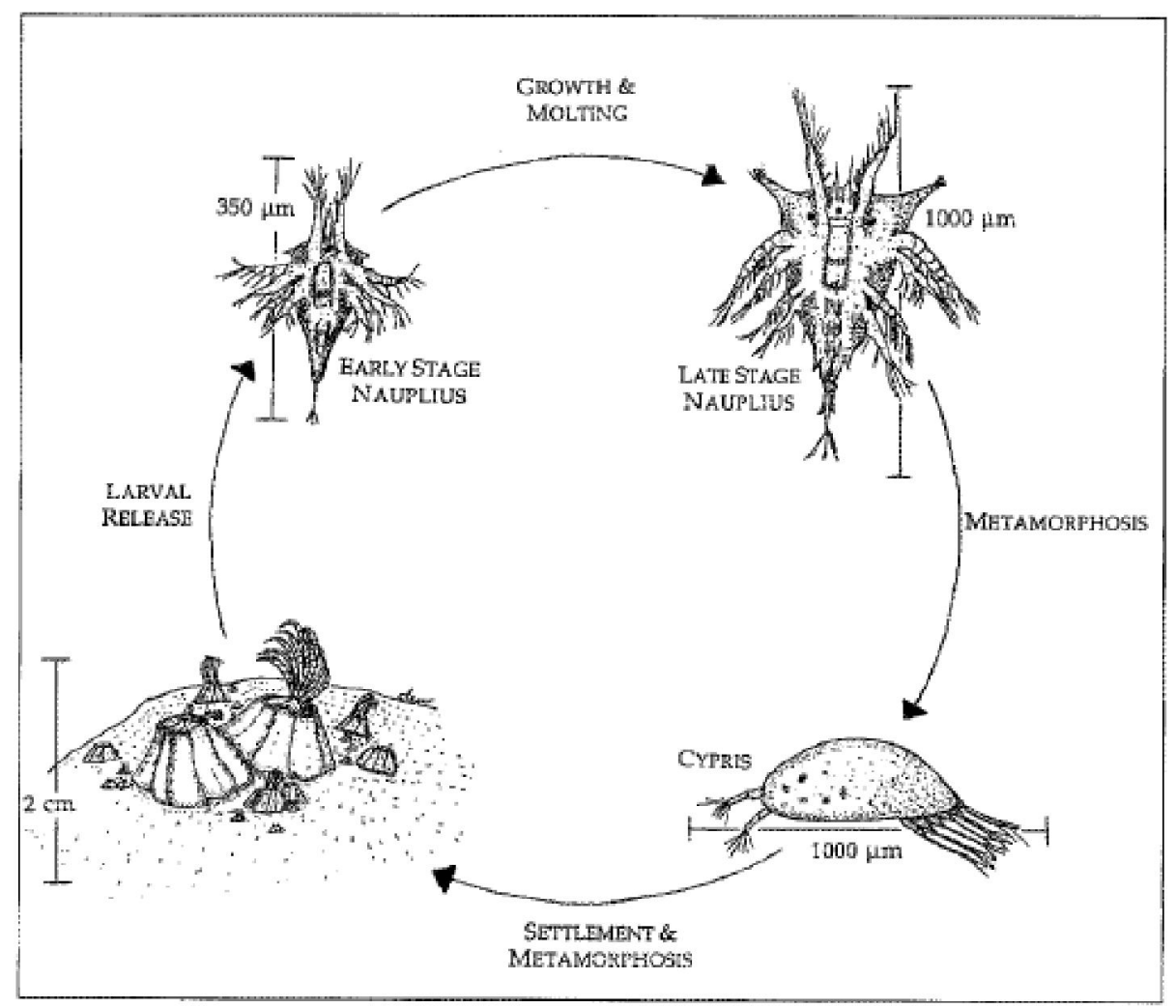

Figure 1. The life cycle of an acorn barnacle (Pechenik et al. 1998)

\subsubsection{Anti-fouling coatings: A problematic solution}

The most effective method of controlling biofouling was the application of toxic antifouling paints or coatings to the desired surface. Most of these coatings contain heavy metals such as tri-organotin or tributyltin (TBT) or cupric oxide (copper based), which leach biocides at a constant rate. Unfortunately, these toxins are not organism specific and have been found to be deleterious in non-target species due to their accumulation in the surrounding environment (Cleary and Stebbing 1985; Stebbing 1985; Wright and Zamuda 1991; Montero et al. 1994; Alzieu 2000; Piola and Johnston 2006). Accumulation of these toxins in bays and harbors is known to cause imposex in 
gastropods and mismatched shell lips in bivalves making them more susceptible to predation (Matthiessen and Gibbs 1998).

\subsubsection{Foul-Release Coatings: Non-toxic Alternatives}

Preparations for the recent TBT prohibition (August 2008), issued by the Marine Environment Protection Committee of the International Maritime Organization, has spurred long term research and new technologies for non-toxic paint alternatives. Over the past twenty-five years there has been a large increase in the development of non-toxic foul-release paints. These coatings are functionally different than antifouling paints in that they allow settlement but rely on weak bioadhesive bonding so that macrofoulers can be swept away with sufficient water flow, predation or their own weight (Berglin et al. 2003). The most widely used foul-release coatings in fouling research are fluorinated polyurethane coatings (PTFE) (Brady and Aronson 2003), hydrocarbon films, and silicone coatings (polydimethylsiloxane, PDMS). One silicone coating in particular, T2 Silastic, produced by Dow Corning, has been used in studies (Stein et al. 2003; Sun et al. 2004; Kavanagh et al. 2005; Holm et al. 2006) as a good model system for the study of foul-release properties against marine organisms. Its chemical properties and structure is well known, it does not leach any toxins, and it is fairly inexpensive.

\subsection{Environmental Influences on Barnacle Adhesion}

\subsubsection{Foul-release coatings at work}

There is a growing literature documenting the mechanisms by which foul-release coatings work and the factors that influence their effectiveness. Such factors include 
surface energy (Brady and Singer 2000; Anderson et al. 2003), coating wettability (Dahlstrom et al. 2004), modulus and thickness (Chaudhury et al. 2005; Wendt et al. 2006), fracture mechanics and materials used (Burnell et al. 1998; Berglin et al. 2003). Long term coating immersion (Wood et al. 2000) and seasonal changes in fouling community across various locations (Swain et al. 2000) have also been tested using foulrelease coatings. However, there is a paucity of research documenting how varying aquatic conditions affect foul-release performance against living organisms (Schultz et al. 2003); Holm et al. in preparation).

The means by which silicon coatings (polydimethylsiloxane elastomers, PDMSe) achieve their foul-release function is still not fully understood. It is believed that the lowsurface free energy $\left(\mathrm{mJ} / \mathrm{m}^{2}\right)$ of the coatings (their low chemical reactivity) may inhibit chemical reactions in the adhesives produced by fouling organisms, though surface free energy of silicone coatings may increase upon immersion due to molecular rearrangement of the silicone-oxygen backbone (Brady and Singer 2000; Anderson et al. 2003).

Coating performance is often quantified by calculating the removal stress per unit attachment area (Critical Removal Stress, CRS) of the fouling organism. Low coating modulus has been correlated with low removal stresses (Berglin et al. 2003; Chaudhury et al. 2005) (Figure 2). Berglin et al. (2003) suggested that an increase in temperature may decrease coating modulus (by increasing molecular mobility) thus increasing interfacial slippage between barnacle and coating. Additionally, size-specific adhesion strength is positively correlated with the square root of the product of a coating's critical surface free energy and modulus (Brady and Singer 2000). Therefore, a combination of low surface 
energy and low modulus is likely to result in weak adhesion and changes in coating modulus due to temperature or altered surface free energy when immersed may be expected to affect critical removal stress. As environmental conditions may influence the physical properties of foul-release coatings and performance and as ships operate in a variety of ocean conditions, it is important that novel coatings be tested under naturally occurring environmental conditions.

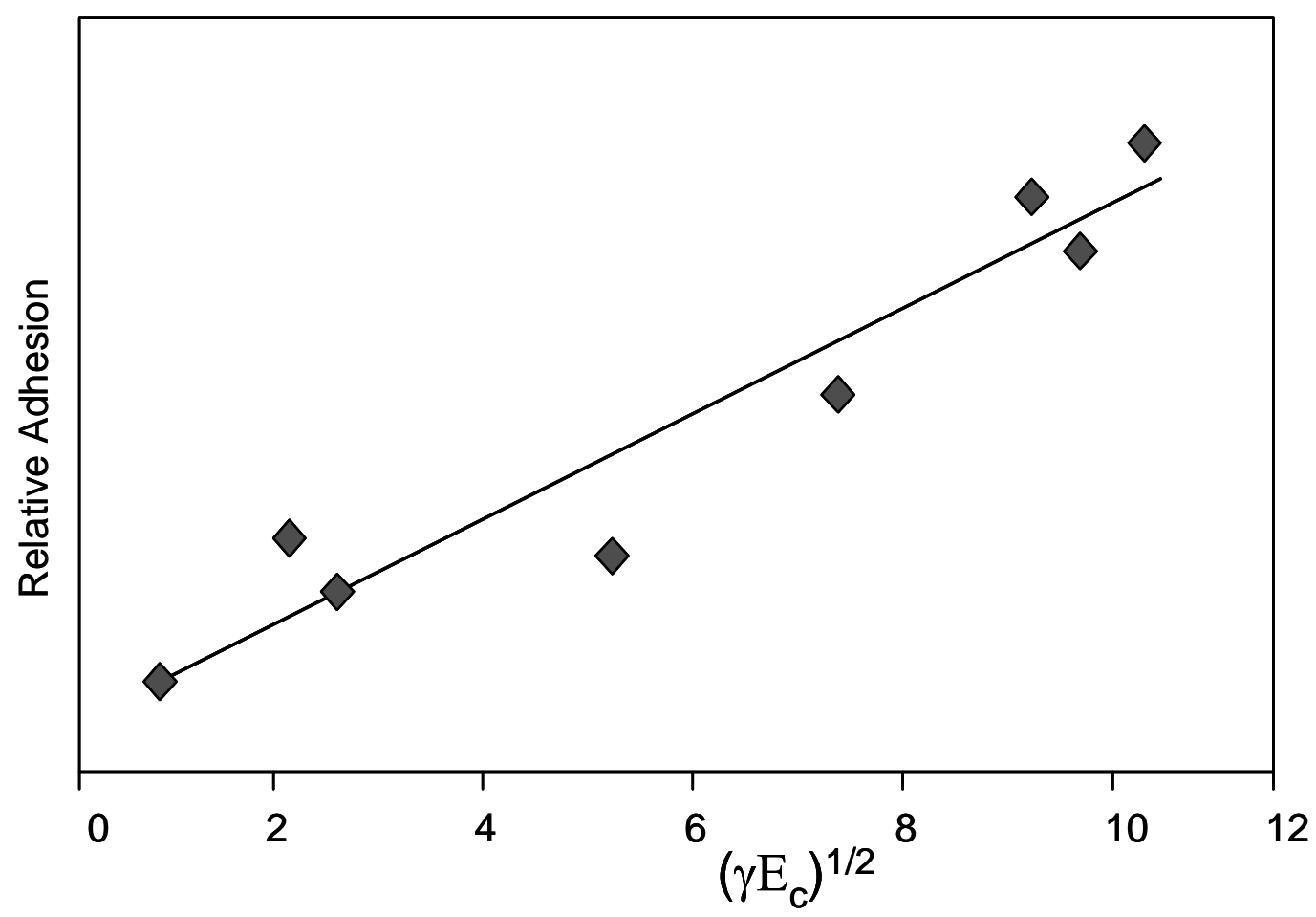

Figure 2. A visualization of an increase in relative adhesion with an increase in the square root of the product of surface free energy and elastic modulus.

\subsubsection{Barnacles in a Dynamic Environment}

Balanus amphitrite (Darwin 1844) is a cosmopolitan, eurythermal and euryhaline species. Within a single year an individual of this species located on the Southern East coast of the United States may experience water temperatures ranging from $12^{\circ} \mathrm{C}$ to over $30^{\circ} \mathrm{C}$ (Figure 3 created from NCCOS online data) and salinities between 15 and 35ppm. 
Both adult and larval barnacles have demonstrated sensitivities to environmental factors. Adults have expressed phenotypic plasticity in cirri length in response to flow force; under higher flow (2-4 m/s), cirri are shorter (Marchinko 2003; Li and Denny 2004). Water temperature is particularly important, with observed effects on barnacle larval recruitment and development (Konya and Miki 1994; Anil et al. 1995; Anil et al. 2001; Pineda and Lopez 2002; Thiyagarajan et al. 2003; Desai et al. 2006), and survival, settlement and molting frequency (Qiu and Qian 1999; Desai and Anil 2004; Pineda et al. 2005).

Clearly, as with all animals, temperature affects growth, survival, and reproduction. Barnacle development within $15^{\circ} \mathrm{C}$ is much slower and resulted in the highest mortality when compared to warmer temperatures $\left(25-30^{\circ} \mathrm{C}\right)$ where development is much more rapid and molting frequency and survivorship are high (Anil et al. 1995). Phenotypic plasticity of thermal tolerance through the production of heat-shock proteins has been well documented in intertidal species such as marine snails, mussels, oysters and barnacles (Roberts et al. 1997; Clegg et al. 1998; Tomanek and Somero 1999; Tomanek 2005; Berger and Emlet 2007). Heat-shock proteins are molecular chaperones whose synthesis is thought to be induced by environmental conditions that are detrimental to cellular protein structure (Parsell et al. 1993). Barnacles experiencing different temperatures have shown to react at a cellular and molecular level which may very well extend to their production of adhesive protein and ability to adhere. Even in light of this information, no research to date has considered the effects of temperature on adult barnacle attachment and adhesive synthesis. In the context of non-toxic coatings, it is important to understand how temperature might affect attachment and the mechanism 
of action, as ships move through many different ocean temperatures and one coating will have to be effective under all circumstances.

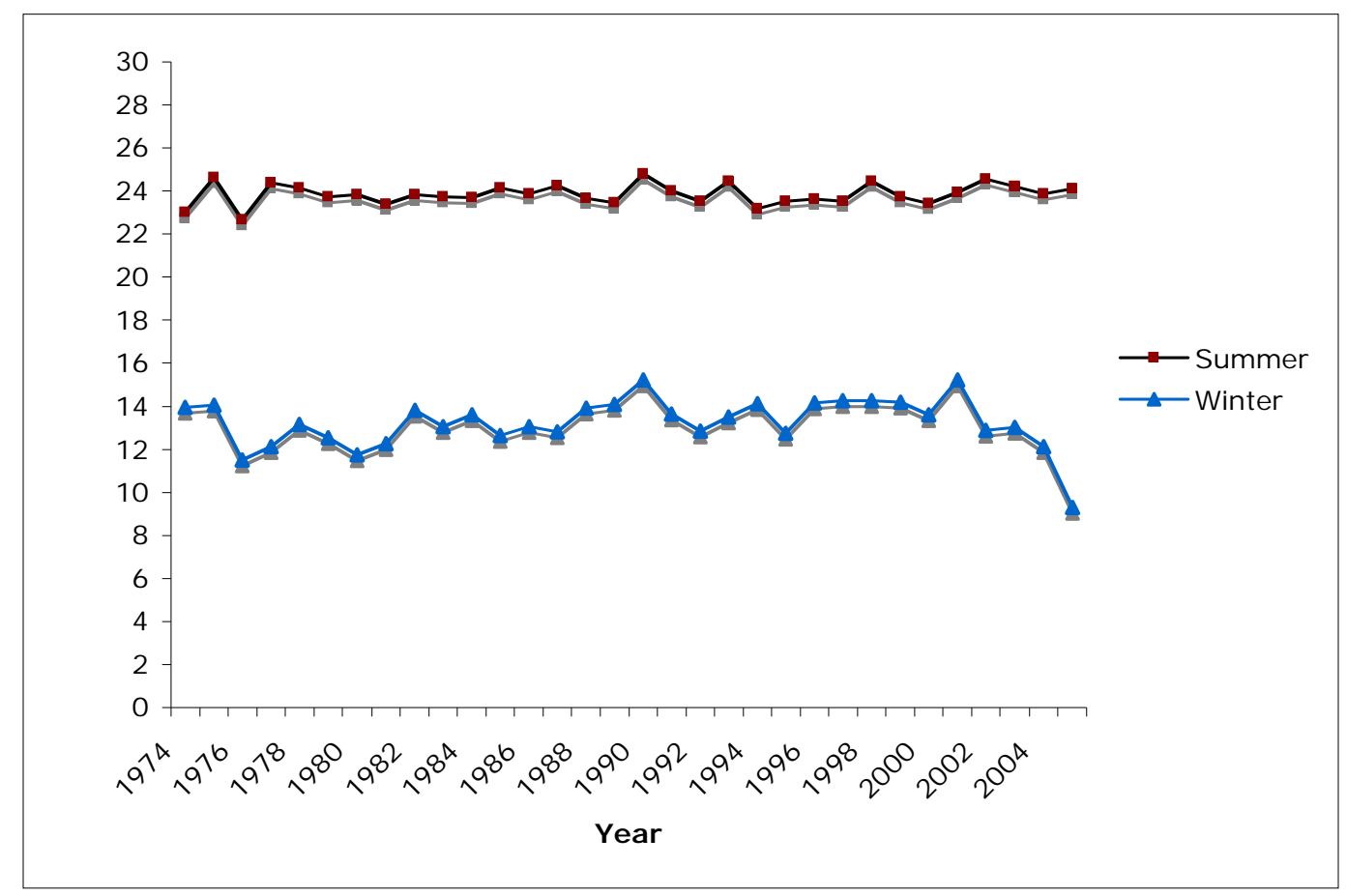

Figure 3. Average biannual water temperatures experienced by $B$. amphitrite found on the coast of Beaufort, NC between 1974 and 1976 (NCCOS).

\subsection{Barnacle Cement}

\subsubsection{A sticky situation}

Barnacles adhere to their permanent adult home during the cyprid larval stage of their life cycle. Behind the cyprid's compound eyes is a pair of cement glands connected by cement ducts to atennular adhesive disks (Walker 1971) originally described by Darwin (1851). Initially the cement is fluid like and produced by granules (secretory vesicles) that swell prior to secretion (Odling et al. 2006). Only a small mass of cement is produced through the atennulae and once the cyprid has secured itself on a substrate, it immediately begins to metamorphose into an adult barnacle (Glenner and Hoeg 1993). 
Within 6 to 8 hours after attachment the cyprid carapace is shed (ectdysis) and the body forms into that of a juvenile barnacle. During the forty-eight hours after ectdysis the cement glands migrate to the perimeter of the newly formed base and cement is produced to secure the organism (Saroyan et al. 1970). More glands develop periodically as the barnacle grows and more cement is needed (Figure 4).
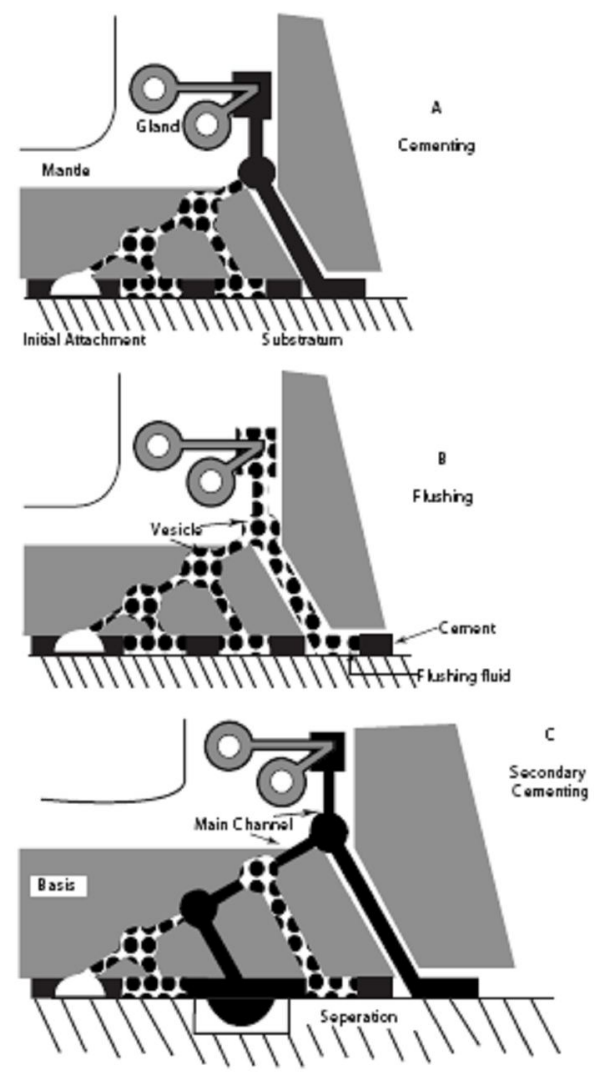

Figure 4. Barnacle cement production diagram (Khandeparker and Anil 2007)

Though not much is know about the composition of cement, many studies have successfully identified changes in barnacle removal stress from various surfaces (Berglin and Gatenholm 1999; Swain et al. 2000; Berglin et al. 2001; Berglin et al. 2003; Sun et al. 2004; Wendt et al. 2006). The study conducted by Sun et al. (2004) shows that the cement, which forms below the basal plate, is a multilayered structure of adhesive plaque. 
They found that the Young's modulus (elasticity) in these layers changes when on different substrata. Their data show that low barnacle adhesion strength correlates with low mean surface layer plaque modulus. Watermann et al. (1997) reported that barnacles growing on PDMS coatings may exhibit a cupped shape base filled with a soft white adhesive. Berglin and Gatenholm (2003) described this phenomenon as a thick layer of white, rubbery mass, which probably is the barnacle primary cement (Figure 5). This physiological change causes a decreased removal stress but has since proven to be a common occurrence due to certain coating properties such as thickness and modulus (Wendt et al. 2006). When the plaque was analyzed with atomic force microscopy (AFM), the image showed that the layer closest to the basal plate was a closely packed granular structure compared to the continuous film-like appearance of the rubbery cement removed from poly(methylmethacrylate) (PMMA). PDMS technology is promising in that it has been proven to significantly reduce barnacle attachment to hard substrata ( $>1.0$ $\left.\mathrm{x} 10^{6} \mathrm{~N} / \mathrm{m}^{2}\right)$ to levels that enable easy removal $\left(1.0 \times 10^{5} \mathrm{~N} / \mathrm{m}^{2}\right)$ (e.g., (Swain et al. 2000 ; Kavanagh et al. 2001; Stein et al. 2003; Kavanagh et al. 2005)). 

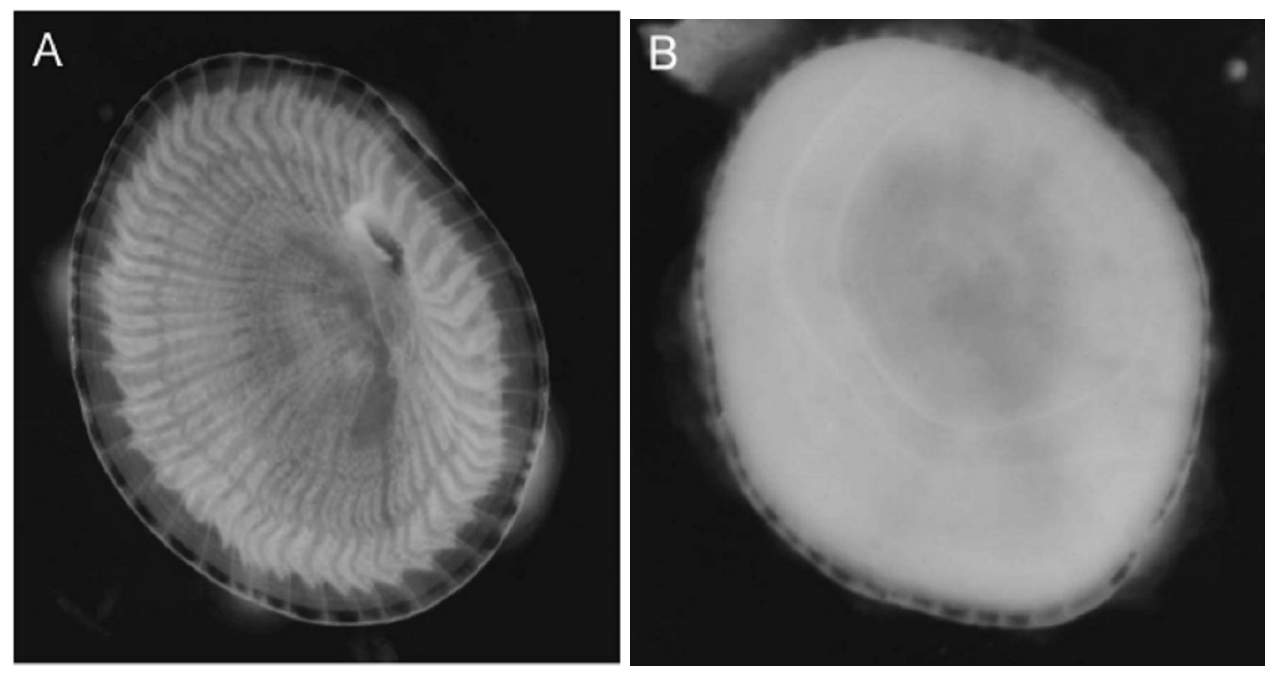

Figure 5. Examples of the various morphologies of a barnacle basal plate grown on an elastomeric surface. A=typical or "flat' morphology; B=atypical or "cupped", morphology (Wendt et al., 2006)

\subsubsection{Determining cement protein composition}

Barnacle cement is interesting because of its insolubility during underwater secretion and the general lack of understanding surrounding mechanisms of adhesion. We do know that it consists mainly of carbohydrates as well as proteins, which are difficult to delineate and are rendered soluble only in sodium dodecyl sulfate (SDS) (Naldrett and Kaplan 1997). Few methods have been successful at rendering the cement soluble enough to identify the amino acid composition of its proteins (Kamino 2001).

Kamino et al. (1996) partially solubilized Megabalanus rosa cement in formic acid and characterized its proteins into three fractions, Soluble Fraction 1 (SF1), SF2 and Insoluble Fraction (IF). With SDS PAGE three major polypeptides were purified from SF1 (60k, 57k and 47k) and a 60k polypeptide from SF2 (since renamed Mrcp-68k). The IF was solubilized by suspension in $1 \%$ cyanogen bromide $(\mathrm{CNBr})$ in $70 \%$ formic acid and agitated for 24 hours. Through SDS PAGE, the IF was found to contain 8 cyanogen bromide (CB) peptides (CB1-8) in SDS PAGE. Within CB8 (4.2kDa), Leu appeared at 
every one to four amino acid sites. In a later study (Kamino et al. 2000), CB8 was used to design two primers utilized in generating a DNA probe with PCR for cDNA library screening. The resulting 110-bp fragment was subcloned into the SmaI site of $p \mathrm{UC} 19$. A chosen cDNA clone was sequenced and a homology search analysis using BLAST program was conducted. The secondary protein structure was predicted as well. Mrcp$100 \mathrm{k}$ is composed of abundant hydrophobic residues possibly allowing the structure to shelter disulphide bonds thus only high concentrations of DTT and Guanidine Hydrochloride are essential for protein suspension.

Walker (1972) suggested disulfide bond formation may play an important role in adhesive curing. Disulfide bonds increase the effective local concentration of protein residues and lower the local concentration of water molecules, creating a more stabile protein (Kamino et al. 2000). Kamino (2001) developed a different method to render $90 \%$ of the cement proteins soluble, also from the barnacle, $M$. rosa. Using reversedphase HPLC he was able to identify a novel $20 \mathrm{kDa}$ protein and determine that it consists of a Cys-rich repeating sequence. Cysteine is a sulfur-containing amino acid in which the thiol-group side-chains easily form disulfide bonds. It has been suggested this plays a role in preventing these compounds from aggregating in the cement gland tubes.

\subsubsection{Hypothesis}

In light of this molecular data from barnacle cement as well as the evidence for biological responses to environmental variables, we chose to take an integrative approach to biofouling research. First we investigated whether barnacles manifest a response to temperature in their ability to adhere to foul-release coatings. If adhesion strength were 
to have a significant response to temperature, the causative factors within the cement for this response could be examined through protein separation techniques. We hoped to discover differences in protein content or type across temperature treatments in order for specific proteins to be identified and held responsible for the possible changes in adhesion and thus attributed to barnacle adhesive ability to foul-release coatings. 


\subsection{Temperature Affects Critical Removal Stress}

\subsection{Introduction}

In the previous sections, it was described how environmental factors such as temperature, flow and salinity may change the effectiveness of silicon-based foul-release coatings as well as the phenotype or behavior of barnacles. To date, many studies have investigated the interaction between environmental factors and barnacles or between barnacles and coatings, yet there has not been any research on the interaction between barnacle, coating and environment. In order for a coating to be assessed accurately, we must take into account how it will perform under a dynamic environment. Similarly, we cannot assume that barnacles will respond uniformly when their environment is changing.

As mentioned above, barnacle adhesive strength and characteristics (gummy adhesive plaque versus normal hard cement) can be affected by coating type (Watermann et al. 1997; Berglin and Gatenholm 2003; Holm et al. 2005; Wendt et al. 2006) as well as varying factors within a coating such as oil inclusion (Truby et al. 2000; Wood et al. 2000) and thickness (Wendt et al. 2006). Significant variation in adhesive characteristics on silicone were also attributed to genetic relationship of the barnacles (Holm et al. 2005). However, Holm et al. (2005) did not dismiss the possibility that maternal environmental effects could be at play. Barnacles are also known to physically respond to natural conditions and stresses from their surroundings (Roberts et al. 1997; Marchinko 2003; Desai and Anil 2004; Li and Denny 2004). It is very possible, then that adhesion strength is included in their elastic response. Environmental factors may be playing a large roll in barnacle adhesion in combination with coating type, through genetic 
interactions or both but have yet to be tested for. This study attempts to examine one such interaction of barnacle adhesion to foul-release coatings under different environmental temperatures. We predicted temperature and maternal family (genetic relationship) to have a significant effect on barnacle critical removal stress (CRS) and plaque formation type.

\subsection{Materials and Methods}

Three separate experiments investigating the effect of temperature on barnacle adhesion were conducted: two at California Polytechnic State University, San Luis Obispo, USA (CPSLO) between January and April 2007 and another in June 2009. The third experiment was conducted at Duke University Marine Lab in Beaufort, NC, USA (DUML) between June and August 2007 examining the additional effects of genetic family and coating type.

All larvae used in the following experiments were obtained from adult barnacles collected off the sea wall surrounding DUML. Following collection, larvae were treated with the antibiotics, Penicillin G and Streptomycin Sulphate, and fed the diatom Skeletonema costatum throughout the naupliar stages until their metamorphosis into cyprids as described previously (Holm et al. 2005). Barnacles were reared from the cyprid stage at different temperatures on silicone coatings and assayed using shear force removal to obtain the critical removal stress as described below. 
2.2.1 Experiments conducted at CPSLO: Effect of temperature

\subsubsection{Silicon substrata}

Silastic T-2 is a silicone-based material, PDMSe, used as a model coating in several recent adhesion studies (Conlan et al. 2008; E. R. Holm et al. 2006; E. R. Holm et al. 2005; Holm et al. 2009; Stanley and Callow 2007). T-2 coated microscope slides were prepared using silicone resin and silicone curing agent (Dow Corning: T2 Silastic) following the Brennan Research Group Protocol for Making Topographically Modified PDMSe Slides (as described in Hoipkemeier et al. 2004)

\subsubsection{Larval settlement and barnacle rearing}

Cyprids of Balanus amphitrite were shipped overnight from DUML to CPSLO and kept at $4{ }^{\circ} \mathrm{C}$ for twenty-four hours. After cyprids were brought to room temperature they were settled onto $30 \mathrm{~T}-2$ slides, as well as 30 un-coated glass slides, which were used as a control. Twenty to forty cyprids in a drop of filtered seawater (approximately $1 \mathrm{~mL}$ ) were placed on each slide. All slides with larvae were then incubated at $25^{\circ} \mathrm{C}$ for 72 hours and the number of metamorphosed barnacles were counted to ensure at least $50 \%$ settlement and to note if settlement differed between the test coating and control. Following this check, slides were individually placed into $150 \mathrm{~mm}$ x $20 \mathrm{~mm}$ Petri dishes and submerged with $15 \mathrm{~mL}$ each of the unicellular algae Dunaliella sp. and the diatom Skeletonema costatum. Ten of each T-2 and glass slides were then placed into incubators at $15^{\circ} \mathrm{C}, 25^{\circ} \mathrm{C}$ and $30^{\circ} \mathrm{C}$ on a $12 \mathrm{hr}$ light/dark cycle. Barnacles were fed both algae and diatom three days a week (Monday, Wednesday, Friday) for four weeks, after which time they were switched to $1 \mathrm{~mL}$ Artemia sp. and $40 \mathrm{~mL}$ filtered natural seawater. 


\subsubsection{Shear removal}

Thirteen weeks after settlement, photographs were taken of the underside of each barnacle basis through the clear substrate (glass or T2) using a Canon EOS 10D digital camera attached to an Olympus SZX12 dissecting microscope. From these images, basal area was calculated using NIH's ImageJ image analysis software. Directly following the image capture, barnacles were tested for shear force of removal using standard methodology (see Wendt et al. 2006, Callow et al. 2007). Slides were clamped vertically to a shear test apparatus, which consists of an IMADATM ZP-4 digital force gauge (2 $\mathrm{kg})$ mounted on an IMADATM SV-5 motorized stand. The force gauge was attached to a motorized stand that moves a shearing head parallel to the coating surface at an average speed of approximately $67 \mu \mathrm{m} \mathrm{s}^{-1}$. Force was applied to basal/lateral plate junction of each barnacle until the basal plate released from the substrate or broke. Peak force of removal was then recorded and used to calculate critical removal stress (force per unit area) for each barnacle. Having a motorized gauge removes variability in removal force due to shearing speeds (Wendt et al. 2006; Callow et al. 2007), which can alter modes of failure (Kavanagh et al. 2005). The glass slides were clamped into a custom-built Plexiglas chamber that allowed complete submersion of coatings during release tests. Water temperature within this chamber was maintained at the corresponding temperature in which each barnacle grew.

\subsubsection{Critical removal stress analysis}

Critical removal stress (CRS) was calculated by dividing the removal force $(\mathrm{N})$ by the basal area $\left(\mathrm{mm}^{2}\right)$. Considering CRS rather than absolute removal force allows 
temperature effects on adhesion to be separated from size differences between barnacles grown at different temperatures. A minimum size of 3 to $5 \mathrm{~mm}$ diameter of basal plate has been suggested by Kavanagh et al. (2005) and Callow et al. (2005) to minimize the potential for bias caused by possible non-linear relationships between removal force and size. Further, barnacles smaller than $3 \mathrm{~mm}$ tend to break when subjected to shear removal. Thus, our data include only barnacles equal to or greater than $4 \mathrm{~mm}$ average diameter. Statistical analysis was conducted using an ANOVA with Type III Sums of Squares in R (R 2.9.1 Development Core Team). Data were discarded if the basal plate fractured or more than $10 \%$ remained on the slide after the shear test.

To test for possible effects of attachment (basal) area on our results, CRS was plotted against basal area and a linear regression analysis performed in Statview (Windows 5.0.1, SAS Institute Inc). An ANCOVA was run on grouped CRS data across temperatures to analyze the relationship between CRS and area. Coefficients of determination $\left(\mathrm{R}^{2}\right)$ values for each temperature treatment were also calculated.

\subsubsection{Abnormal cement measurement}

Images were later analyzed for basal area percent of abnormal cement (Holm et al. 2005; Wendt et al. 2006). Ratios of barnacles containing abnormal cement on $>10 \%$ basal area were calculated for each temperature. To determine statistical differences in frequency of abnormal cement between temperatures, a nonparametric multiple comparisons test was run followed by a post hoc Behrens-Fisher-Test in R. 
2.2.2 Experiments conducted at DUML: Effect of temperature, coating type, and genetics

\subsubsection{Expanded research design}

Holm et al. (2005) found the presence of genetic variation and possible genetic control of phenotypic variation in tenacity of barnacle adhesive. To investigate plausible genetic factors in barnacle adhesive mechanisms under different temperatures the temperature/coating treatments included maternal family groups as a blocking factor. Maternal families were defined as larvae corresponding to a single maternal parent barnacle (Holm et al. 2000). Three families, labeled 17, 18, and 19 were collected (as in Holm et al. 2005) and randomly assigned to the two substrata in equal proportion to be placed in all three temperatures.

\subsubsection{Silicon substrata}

Silastic T2 (Dow Corning Corporation) as well as International Veridian (International Paint Ltd) commercially available foul-release coatings, were used as substrata. As described in Holm et al. (2005) both coatings were prepared and applied to $7.6 \times 15.2 \times 0.64 \mathrm{~cm}$ glass panels. Panels were assigned to each condition using a random number chart.

\subsubsection{Larval settlement and barnacle rearing}

Nauplii were collected from adult barnacles near DUML in such a way as to preserve family groups. Female parents were collected over a meter apart to ensure genetic separation between families. 
As in the Cal Poly experiment, 20-40 cyprids were settled on to each panel and allowed to metamorphose until 50\% settlement was reached. Panels were then placed into 8 X 8 X 14cm plastic containers filled with 750mL aged filtered seawater (ASW) and $20 \mathrm{~mL} /$ day $S$. costatum. Juvenile adults were kept at about $30^{\circ} \mathrm{C}$ (ambient air temperature) for two days before being moved into $15^{\circ} \mathrm{C}$ and $25^{\circ} \mathrm{C}$ incubators on a $12: 12$ light-dark cycle. The plastic bins were cleaned and filled with fresh ASW every two days. Barnacles to be placed in $15^{\circ} \mathrm{C}$ were first held at $25^{\circ} \mathrm{C}$ for one week. After the first week the amount of $S$. costatum was increased to $40 \mathrm{~mL} /$ day and Dunelliela sp. was gradually incorporated into their diet until the majority of barnacles were large enough to ingest Artemia sp. Containers were covered with plastic wrap and aerated to prevent evaporation. Barnacles were measured for critical removal stress after ten weeks of growth.

\subsubsection{Critical removal stress analysis}

Panels were secured in place while barnacles were pushed off using a hand-held force gauge as described by ASTM (Anonymous, 1997). As in (Shimpo MF-5lb,\#9395310, Cole-Parmer, Vernon Hills, IL) shear force was applied at a constant rate (approximately $4.5 \mathrm{~N} \mathrm{~s}^{-1}$ ) until the barnacle was removed. Removal was performed by one researcher to reduce variation associated with users. Using calipers, the area of attachment was calculated for each barnacle by measuring three diameters at $180^{\circ}, 45^{\circ}$ and $90^{\circ}$ across the base plate. Maximum force of removal was divided by basal area to obtain CRS. Analysis of CRS of barnacles on T2 was done using a GLM Mixed Model ANOVA with pooled family and panel terms. Data collected from barnacles raised on 
Veridian was analyzed using a 2-way ANOVA with pooled Temperature/Family interaction and Panel terms in SAS/STAT (SAS V. 8.2). Individuals were also noted for percent cover of abnormal basal plaque formation (Holm et al. 2005; Wendt et al. 2006) which was analyzed in SAS.

\subsection{Results}

\subsubsection{Growth}

Barnacles raised at $15^{\circ} \mathrm{C}$ grew more slowly than those at $25^{\circ} \mathrm{C}$ or $30^{\circ} \mathrm{C}$. However, growth rate did not have a linear relationship with temperature and was lower in the $30^{\circ} \mathrm{C}$ treatment than in the $25^{\circ} \mathrm{C}$ treatment. (Figure 6). Barnacles in $15^{\circ} \mathrm{C}$ were much smaller $\left(\operatorname{avg} 10.35 \mathrm{~mm}^{2}\right)$ compared to $25^{\circ} \mathrm{C}\left(\operatorname{avg} 23.82 \mathrm{~mm}^{2}\right)$ and $30^{\circ} \mathrm{C}\left(\operatorname{avg} 19.97 \mathrm{~mm}^{2}\right)$.

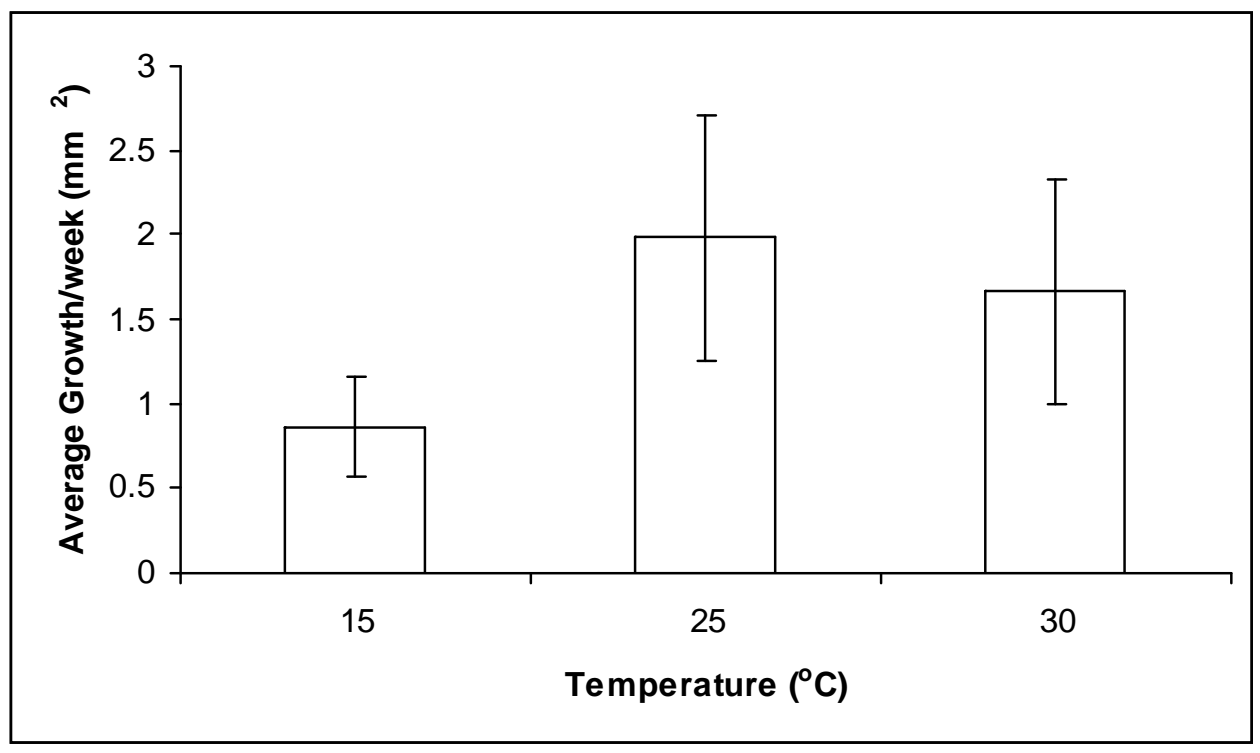

Figure 6. Average growth per week of barnacles cultured on T2 under different temperatures at CPSLO. The average growth rate at $15^{\circ} \mathrm{C}$ was $0.864 \mathrm{~mm}^{2} / \mathrm{wk}$, at $25^{\circ} \mathrm{C}$ rate $=1.99 \mathrm{~mm}^{2} / \mathrm{wk}$, and at $30^{\circ} \mathrm{C}$ rate $=1.66 \mathrm{~mm}^{2} / \mathrm{wk}$. 

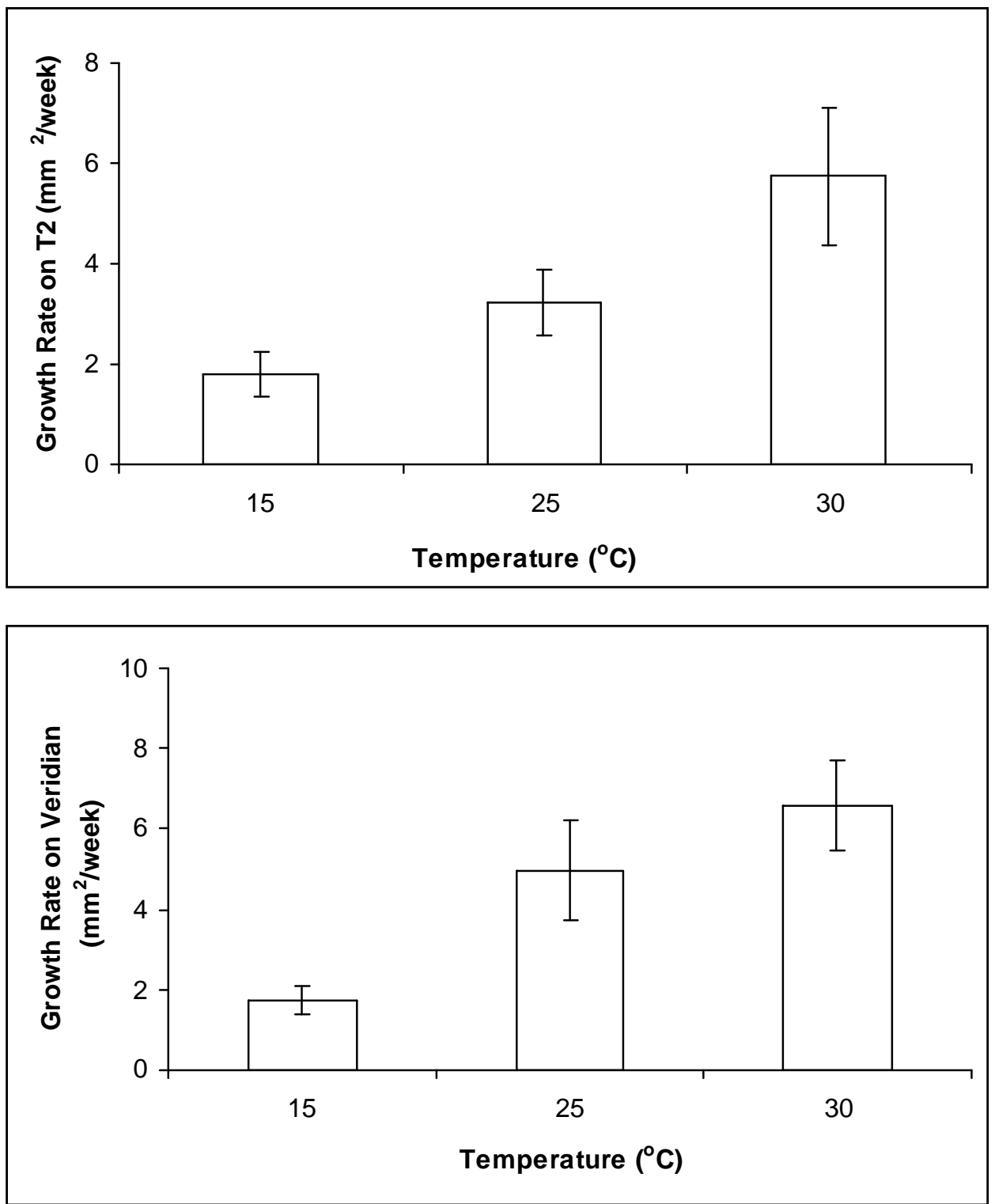

Figure 7. Average growth per week of barnacles raised on T2 (top) and Veridian (bottom). Barnacles on both coatings showed similar positively correlated growth trends as temperature increased. Average barnacle growth rate on $\mathrm{T}-2$ at $15^{\circ} \mathrm{C}=1.80 \mathrm{~mm}^{2}$, $25^{\circ} \mathrm{C}=3.24 \mathrm{~mm}^{2}$ and $30^{\circ} \mathrm{C}=5.74 \mathrm{~mm}^{2}$ and for Veridian at $15^{\circ} \mathrm{C}=1.74 \mathrm{~mm}^{2}, 25^{\circ} \mathrm{C}=4.97 \mathrm{~mm}^{2}$ and $30^{\circ} \mathrm{C}=6.56 \mathrm{~mm}^{2}$. 


\subsubsection{Critical removal stress}

A significant difference in CRS of barnacles was found between each temperature at CPSLO. The average CRS (megapascals) for barnacles reared at $30^{\circ} \mathrm{C}$ was lower (0.138mpa) than the average CRS from those at $25^{\circ} \mathrm{C}(0.172 \mathrm{mpa})$ which was also significantly lower than for those at $15^{\circ} \mathrm{C}(0.215 \mathrm{mpa})$ (Type III ANOVA; $\mathrm{F}=9.62$, $p=0.0007$ ) (Figure 8).

This negative relationship between CRS and temperature was also found in data obtained at DUML, with average CRS significantly lower at $25^{\circ} \mathrm{C}$ than at $15^{\circ} \mathrm{C}$ on both T2 and Veridian (Figure 9). CRS also differed between coatings at each temperature. On Veridian, the average CRS was $0.117 \mathrm{mpa}$ at $15^{\circ} \mathrm{C}$ and was $0.081 \mathrm{mpa}$ at $25^{\circ} \mathrm{C}$ (ANOVA with pooled Temperature X Family and panel terms; $\mathrm{F}=7.62, p=0.0020$ ) The average CRS on $\mathrm{T} 2$ at $15^{\circ} \mathrm{C}$ was $0.173 \mathrm{mpa}$ and was $0.120 \mathrm{mpa}$ at $25^{\circ} \mathrm{C}$ (Mixed Model ANOVA; $\mathrm{F}=8.19, \mathrm{p}=0.0458$ ). (Figure 10). Results were analyzed in the statistical program R 2.9.1 (R Development Core Team 2008) using a Type III Nested ANOVA and Tukey's HSD post hoc. 


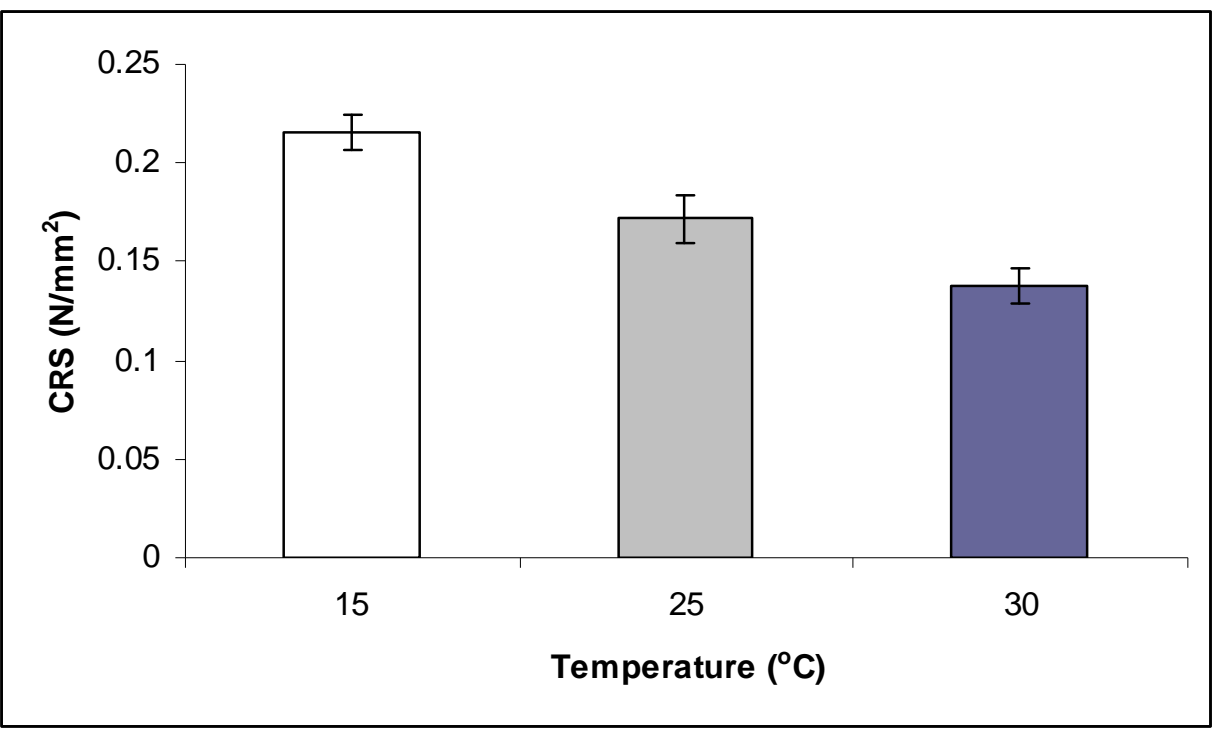

Figure 8. Average CRS of barnacles cultured at Cal Poly under $15^{\circ} \mathrm{C}, 25^{\circ} \mathrm{C}$, and $30^{\circ} \mathrm{C}$ (ANOVA with Type III Sums of Squares, F= 9.62, p=0.0007).

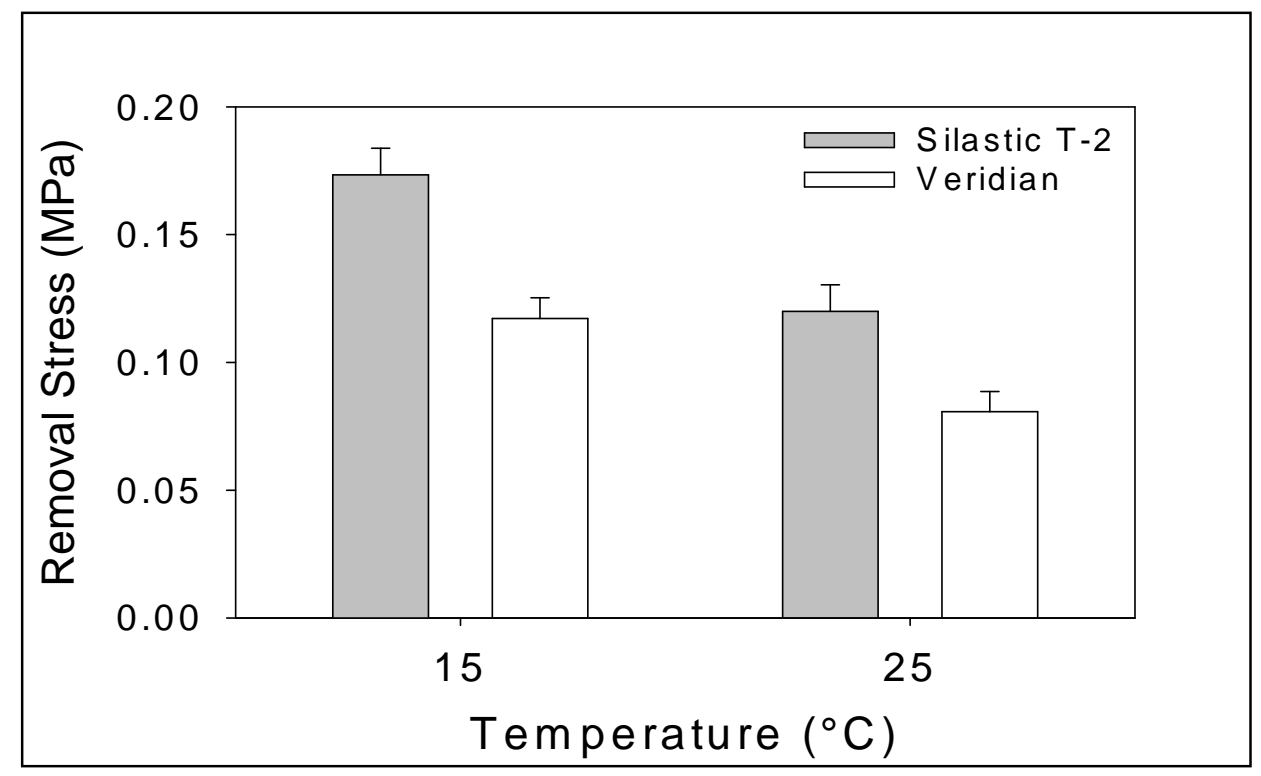

Figure 9. Average CRS is significantly different between coatings as well as between temperatures at DUML. 


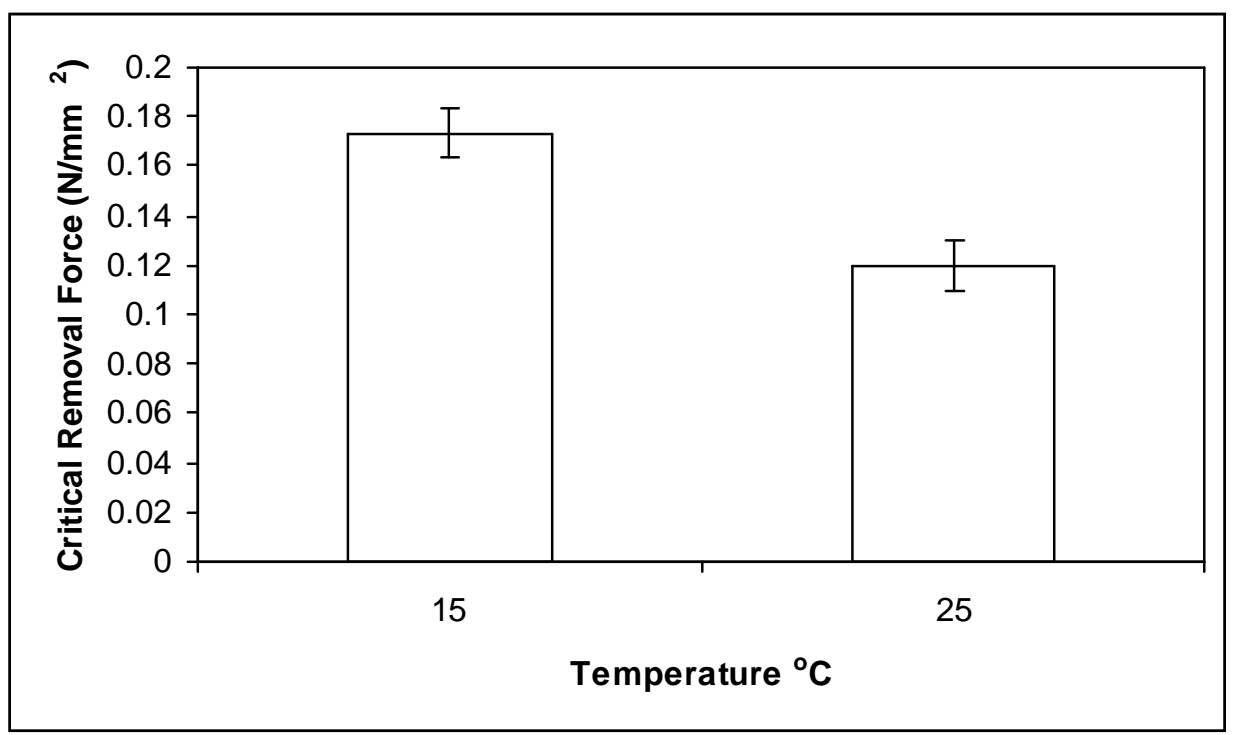

Figure 10. Average CRS for barnacles raised under $15^{\circ} \mathrm{C}$ and $25^{\circ} \mathrm{C}$ on T2 at DUML. Analysis was done using a GLM Mixed Model ANOVA with pooled family and panel terms $(\mathrm{F}=8.19$ and $p=0.0458)$.

To ensure our CRS results were not biased due to barnacle size, CRS was plotted against basal area. Differing trend lines and low R-squared values suggest there is no effect of size on CRS (Figure 11). 


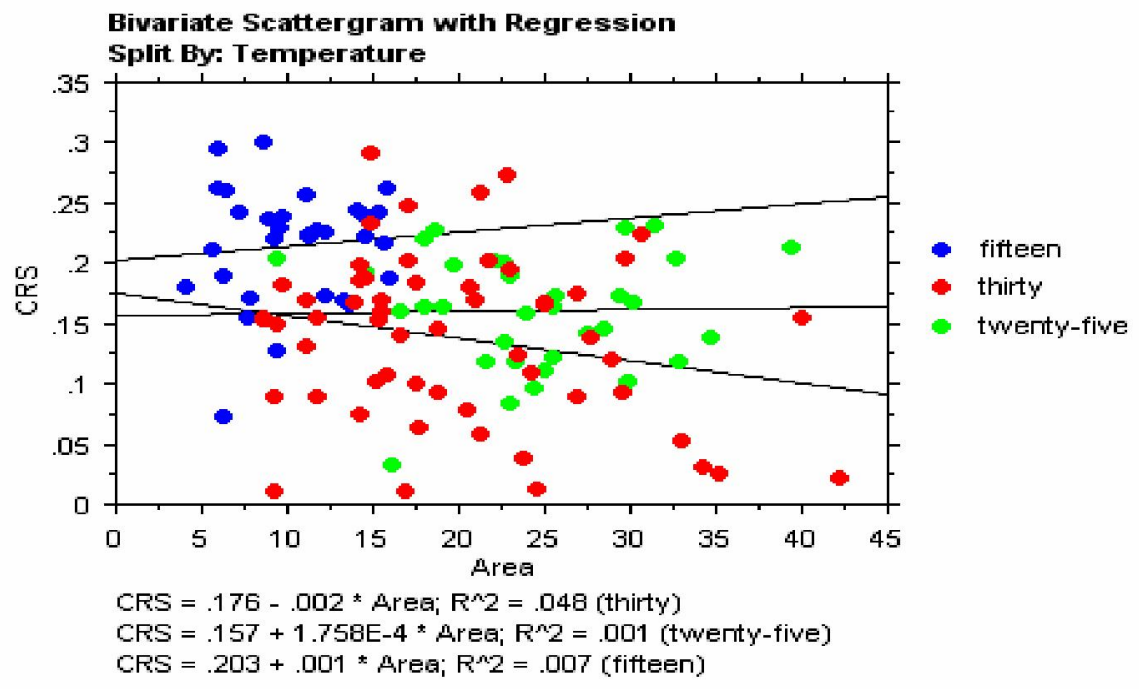

Figure 11. CRS data from each temperature treatment plotted against basal area. Trend lines and corresponding R-squared values are shown for each temperature treatment (ANCOVA, $\mathrm{p}=0.399$ ).

\subsubsection{Family groups}

Three of the four family treatments on T2 (17, 18 and 19) and two of the four families on Veridian (17 and 19) yielded enough data from each temperature to be considered in the analyses. Family did not have a significant effect on CRS nor did it determine the percentage of barnacles with abnormal adhesive. Family 17 did, however, have a different trend across temperatures than family 18 and 19 when on T2 (Figure 12). On Veridian, the two families (17 and 19) had similar trends in CRS to each other across temperatures (Figure 13). The family effect on CRS across temperatures was not significant $(\mathrm{P}=0.1975, \mathrm{~F}=1.56)$, and was excluded from the final ANOVA model. 


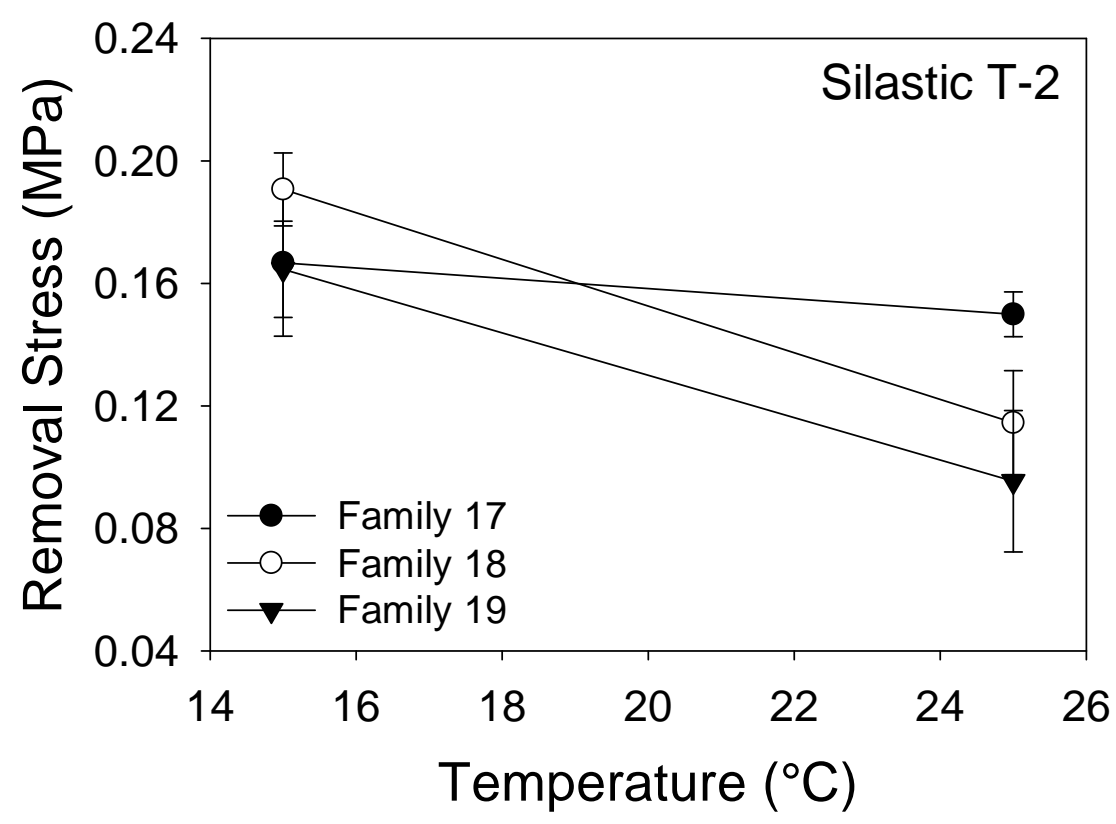

Figure 12. Varied trends in CRS (y-axis) due to temperature between three family groups reared on Silastic T-2. Family 17 CRS had a neutral relationship to temperature where both family 18 and 19 had a negative correlation to temperature.

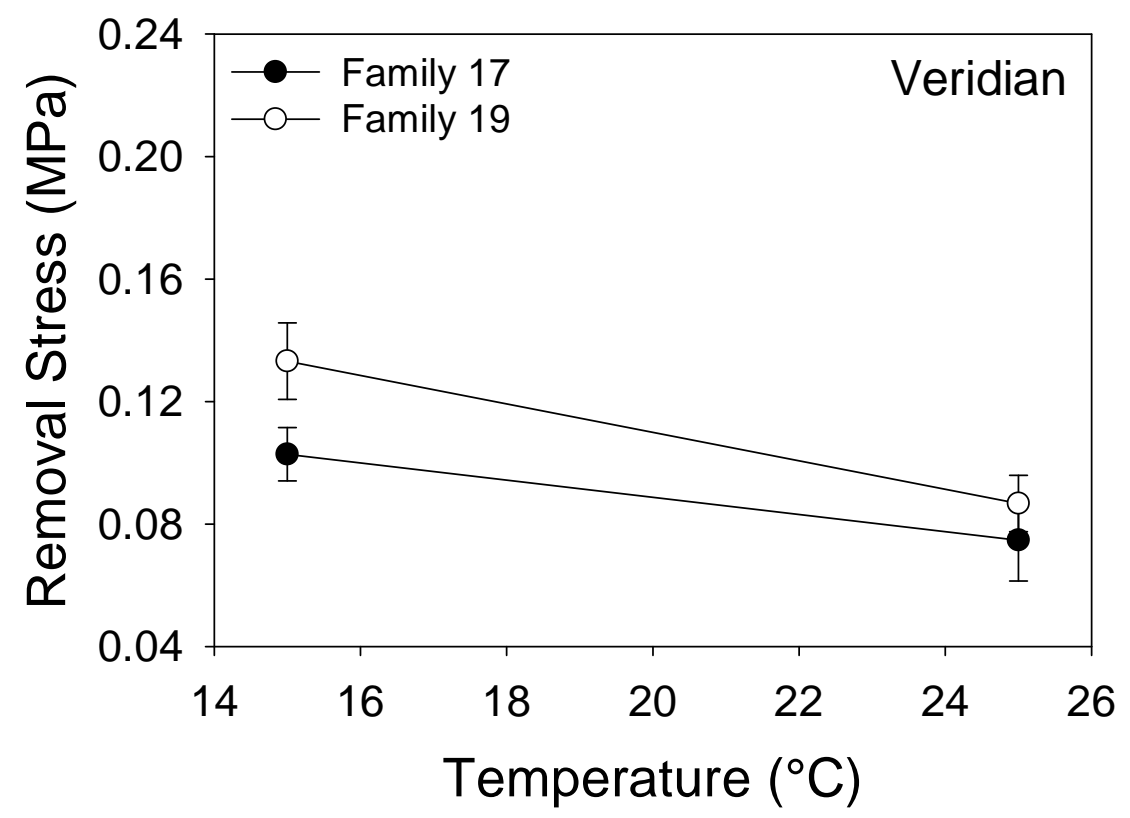

Figure 13. A similar trend is seen in CRS (y-axis) across temperatures for both families though Family group 19 had an overall higher CRS. 


\subsubsection{Abnormal Cement Ratio}

Directly following shear removal of each barnacle, cement structure was graded based on the percent cover of "gummy" or abnormal adhesive plaque on each basis. There was no significant difference in frequency of barnacles with greater than $10 \%$ basal coverage of abnormal cement across temperatures at DUML(Figure 14) and only $15^{\circ} \mathrm{C}$ barnacles from CPSLO showed a significantly lower proportion of abnormal cement. The comparison of temperatures at CPSLO showed mean frequency at $15^{\circ} \mathrm{C}$ to be significantly different from $25^{\circ} \mathrm{C}(\mathrm{p}<0.001)$ as well as $30^{\circ} \mathrm{C}(\mathrm{p}<0.001)$ but no difference was found between the higher temperatures $(\mathrm{p}=0.99)$ (Figure 15).

Analysis of barnacles at DUML did however show a trend towards differing frequencies of abnormal cement due to coating type. A higher percentage of barnacles with basal plates containing greater than $10 \%$ abnormal cement were found on Veridian $\left(100 \%\right.$ at $15^{\circ} \mathrm{C}$ and $85 \%$ at $\left.25^{\circ} \mathrm{C}\right)$ than $\mathrm{T} 2\left(70 \%\right.$ at $15^{\circ} \mathrm{C}$ and $63 \%$ at $\left.25^{\circ} \mathrm{C}\right)$ (Figure 16) supporting previous findings (Holm et al. 2009). Barnacles reared on Veridian also had lower CRS, which coincides with Wendt's (2006) conclusion that softer cement has a lower adhesive ability. Even so, barnacles on both substrata showed discrepancies in CRS across temperatures, regardless of the similar percent of abnormal cement coverage.

Frequency of barnacles with $>10 \%$ abnormal cement basis within each temperature at CPSLO differed from the trend frequency at DUML (Figure 10). There was virtually no abnormal adhesive cement found on barnacles reared at $15^{\circ} \mathrm{C}(<1 \%)$. Also, a much lower frequency of abnormal cement was found on $25^{\circ} \mathrm{C}(16.5 \%)$ and $30^{\circ} \mathrm{C}$ (19.3\%) barnacles from CPSLO than from DUML. 


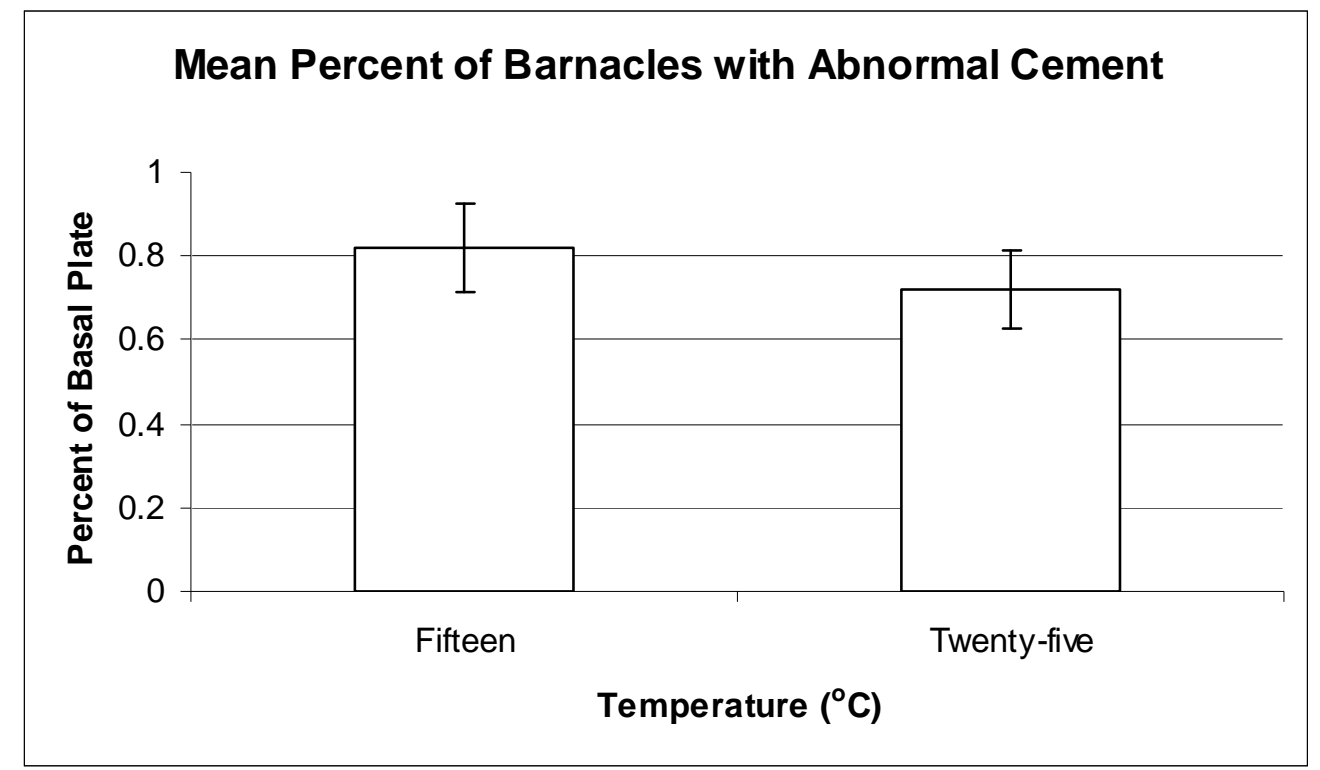

Figure 14. DUML: Mean frequency of abnormal base plates found under each temperature with pooled substrate averages.

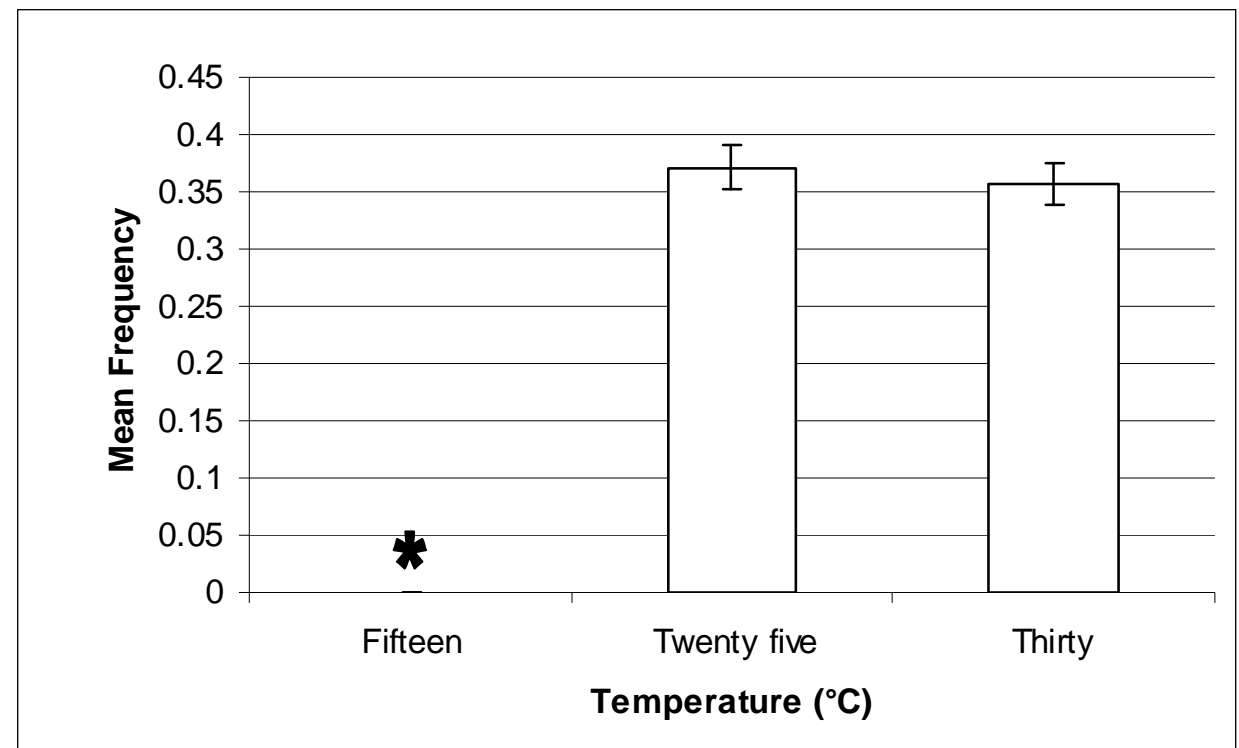

Figure 15. Cal Poly: Proportion of barnacles at each temperature showing greater than $10 \%$ abnormal basal area. Barnacles at $15^{\circ} \mathrm{C}$ did not show significant signs of gummy cement. 


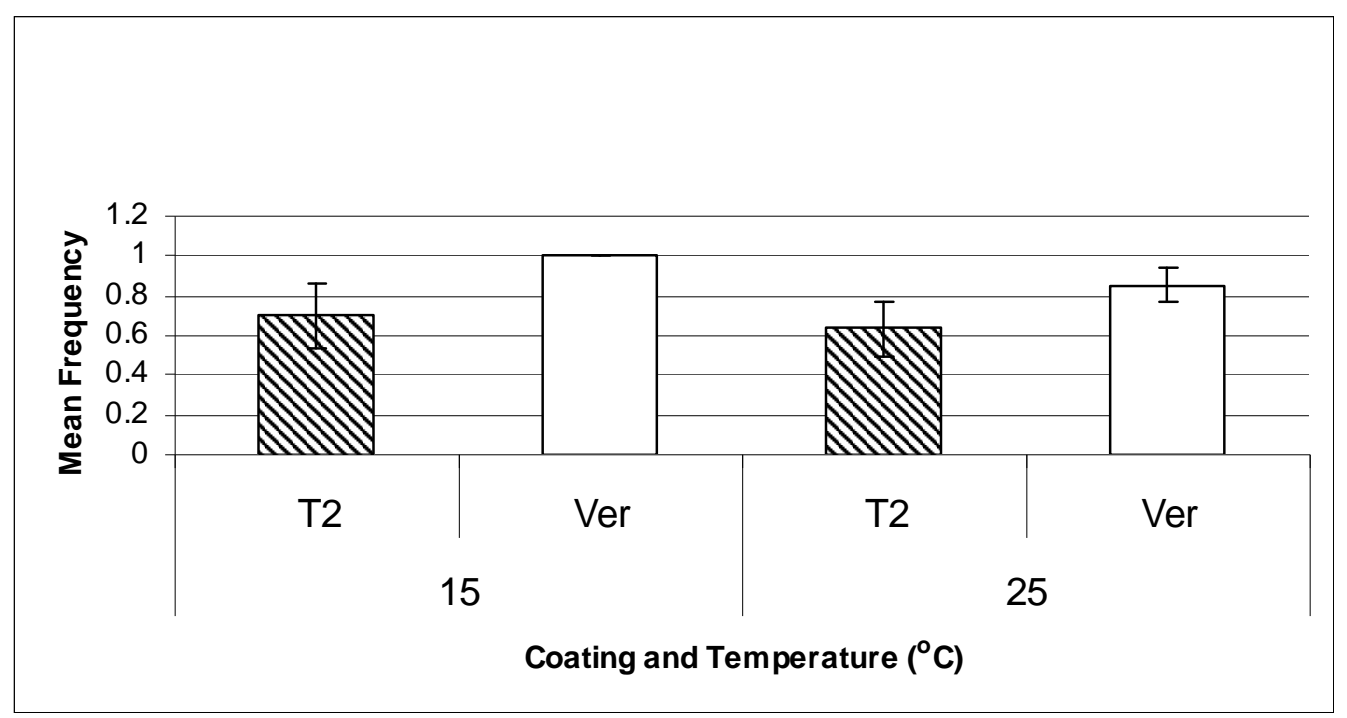

Figure 16. DUML: Mean frequency of abnormal base plates found under each temperature on both substrata. Though there is a trend towards an effect by coating, differences were not statistically significant.

\subsection{Discussion}

\subsubsection{Temperature Effects on Critical Removal Stress}

In our current study, we investigated a significant interaction between fouling organism, foul-release material, and an environmental factor (i.e. temperature). The critical removal stress of $B$. amphitrite from two silicon coatings varied across naturally occurring oceanographic temperatures. To our knowledge, this is the first demonstration that barnacle cement function can be altered by the temperature at which it is secreted. Given the negative, global economic and ecological implications from marine biofouling, it is imperative scientists examine this problem from both a materials science and organismal perspective. Progress in antifouling technology requires developmental and physiological research of fouling organisms. Our data contribute to broadening and 
deepening the basic understanding underlying physiological processes associated with attachment of barnacles, a pervasive and problematic fouling animal.

CRS was plotted against basal area to ensure size was in fact being accounted for within the CRS calculation. The low $\mathrm{R}^{2}$ values indicated that variability in CRS across temperature treatments was not being determined by basal area.

Organisms from highly varying thermal environments, such as B. amphitrite that experience a large seasonal shift in oceanic temperature, are more capable of modifying physiological function (Prosser 1991). Environmental temperature has shown to play a strong role in all barnacle life history stages (Qiu and Qian 1999; Desai and Anil 2004; Pineda et al. 2005) and as well as adhesive ability, as our study suggests. Within cool oceanographic temperatures, barnacles may be more difficult to remove from foul-release hull coatings than within warm temperatures. Even more critical now to efficient fouling research is the temperature at which coatings are tested for foul-release ability (e.g, Callow et al. 2007). Rearing temperatures of B. amphitrite should be standardized across and within test facilities if coating performance is to be compared across experiments. Already test methods across facilities vary greatly and the novel coating performance data at different temperatures is extremely limited. Results from this study underline the importance of testing coatings within conditions they will be facing when commercially utilized.

\subsubsection{Genetic relationship and CRS}

Past and current research has shown how differing environmental factors such as flow force and temperature, give rise to phenotypic plasticity in barnacles (Konya and 
Miki 1994; Anil et al. 2001; Marchinko 2003; Li and Denny 2004). The degree to which phenotypic or functional variation is expressed within a population is ultimately dependant on the genetic connectivity of the organisms. Holm et al. (2005) argued for the presence of genetic variation in adhesive plaque characteristics. The current test of whether this genetic variation translated to functionality did not prove a significant effect of maternal family on CRS. These results support similar findings by Holm et al. (2009). However, the differing (positive, neutral and negative) correlations to temperature for each family imply heritable components to the CRS x temperature interaction. Simplified heritability tests involving only one coating type, with family and temperature as independent variables, could help determine the presence of genetic control on adhesive variation.

\subsubsection{Cement response to temperature}

Although data suggest that temperature influences CRS of $B$. amphitrite, it is unknown by what means the adhesive is affected. If temperature were to change the physical structure of the adhesive, there could very possibly be a change in the viscosity of the cement, thus changing its tenacity. Viscosity describes fluids' resistance to flow. Recently formed, uncured cement has a similar viscosity to water. At $15^{\circ} \mathrm{C}$ pure water has a viscosity of $1.1 \times 10^{-3} \mathrm{~kg} /(\mathrm{s} \cdot \mathrm{m})$ and at $25^{\circ} \mathrm{C}$ is $8.9 \times 10^{-4} \mathrm{~kg} /(\mathrm{s} \cdot \mathrm{m})$, a $21 \%$ increase over ten degrees Celsius. Kavanagh et al. (2005) described a viscous adhesive interface between the substrate and barnacle basal plate. The hypothesized fluid interface would be particularly susceptible to changes in viscosity, which would suggest resulting changes to adhesion. Even so, our data suggest this is not the case. By switching barnacles 
between temperatures just before removal, we tested the effects of viscosity within the interfacial layer. Critical removal stress was only affected by rearing temperature and did not change as a function of removal temperature. Ideally, using a rheometer, changes in viscosity as the cement cures under different temperatures could be measured. This is difficult however, due to the nature of extracting cement from barnacles in a pure liquid (uncured) form. Not only does the cement begin to stiffen rapidly in air but one does not often obtain more than $3 \mu 1$ of uncured cement per barnacle.

\subsubsection{Abnormal cement production}

Directly following shear removal of each barnacle, cement structure was graded based on the percent cover of "gummy" or abnormal adhesive plaque on each basis. There was no significant difference in frequency of barnacles with greater than $10 \%$ basal coverage of abnormal cement across temperatures at DUML and only $15^{\circ} \mathrm{C}$ barnacles from CPSLO showed a significantly lower proportion of abnormal cement. The comparison of temperatures at CPSLO showed mean frequency at $15^{\circ} \mathrm{C}$ to be significantly different from $25^{\circ} \mathrm{C}(\mathrm{p}<0.001)$ as well as $30^{\circ} \mathrm{C}(\mathrm{p}<0.001)$ but no difference was found between the higher temperatures $(\mathrm{p}=0.99)$.

Analysis of barnacles at DUML did however show a trend towards differing frequencies of abnormal cement due to coating type. A higher percentage of barnacles with basal plates containing greater than $10 \%$ abnormal cement were found on Veridian $\left(100 \%\right.$ at $15^{\circ} \mathrm{C}$ and $85 \%$ at $\left.25^{\circ} \mathrm{C}\right)$ than $\mathrm{T} 2\left(70 \%\right.$ at $15^{\circ} \mathrm{C}$ and $63 \%$ at $\left.25^{\circ} \mathrm{C}\right)$ (Figure 8$)$. Barnacles reared on Veridian also had lower CRS,. Even so, barnacles on both substrata 
showed discrepancies in CRS across temperatures, regardless of the similar percent of abnormal cement coverage.

\subsubsection{Ecophenotypic response of cement to temperature}

Previous experiments using gastropods examined what changes have taken place within the animals' adhesive in order for it to increase or decrease tenacity. These changes were not a result of environmental factors but may offer insight to the interworkings of barnacle adhesive cement. Work by Smith et al. (1999) compared limpet adhesive mucus to trail mucus and determined there to be differences in the presence of specific proteins. The adhesive contained proteins and carbohydrates roughly two times as concentrated in limpets that were adhering. Smith (2002) later found functional differences as well between the mucus types by testing shear removal of adhering limpets $(125 \pm 49 \mathrm{kPa})$ versus traveling limpets $(2.3 \pm 0.3 \mathrm{kPa})$ resulting in an increased adhesive tenacity by almost two orders of magnitude. Concentration of protein alone, however, was not sufficient to increase tenacity; rather, Smith concluded that changes in protein diversity and composition were likely to play a large role.

Animal gels or mucus have differing tenacities determined by protein size as well. Larger proteins, around $300 \mathrm{kDa}$, interact by covalent bonds and entanglement while smaller proteins 20 to $100 \mathrm{kDa}$ tend to form crosslinks (Smith et al. 2002). Pawlicki et al. (2004) isolated proteins specific to slug and land snail adhesive mucus then added them to commercial polymers. After protein inclusion, qualitative increases in tenacity of the polymers were visible. It was unclear whether the adhesive proteins acted as a catalyst 
for crosslinking of components within the polymers or if the protein interacted with and enabled crosslinking. Barnacle cement is primarily composed of proteins ranging from $3 \mathrm{kDa}$ to upwards of $160 \mathrm{kDa}$ with proteins between $50 \mathrm{kDa}$ and $100 \mathrm{kDa}$ being the most prominent in terms of volume (Kamino et al. 1996; Naldrett and Kaplan 1997). Mori et al. (2007) identified a calcium coupling protein $(20 \mathrm{kDa})$ only found within the primary cement of Megabalanus rosa suggesting cement-specific proteins such as this may relate to the adhesive's incredible ability to cure underwater. Changes in concentration or appearance of these proteins may affect cement tenacity. Such studies propose mechanisms behind invertebrate adhesion and similar approaches using acorn barnacles are being attempted.

\subsubsection{Coating/temperature interaction}

Substrate modulus has also shown to affect CRS of barnacles (Berglin and Gatenholm 2003). An experiment conducted by Berglin et al (2003) found the glass transition temperature $\left(\mathrm{T}_{\mathrm{g}}\right)$ of the PDMSe used, to be as high as $18^{\circ} \mathrm{C}$. Although they found there to be an insignificant increase in surface chemistry between $5^{\circ} \mathrm{C}$ and $50^{\circ} \mathrm{C}$, this study gave rise to questions regarding glass transition temperature and surface chemistry of our test coatings. For both T2 and Veridian, the glass transition temperature $\left(\mathrm{T}_{\mathrm{g}}\right)$ is very low $\left(-100^{\circ} \mathrm{C}\right.$ and $-115^{\circ} \mathrm{C}$ respectively) (Dow Corning and Holm personal communication 2008), well outside the range tested here. It is then unlikely that the coating modulus would have shifted enough to cause the resulting difference in CRS. Similar research would benefit from testing substrate modulus using Electron Force Microscopy and remove uncertainty regarding treatment effects on the coating. 
Moreover, our data on switching temperatures prior to removal support limited changes to the physical properties of coatings at the two temperatures investigated. 


\subsection{Testing the Mechanisms of Temperature Effect on CRS: Proteomics of Barnacle Cement Proteins}

\subsection{Introduction}

Given our recent finding of the functional response of $B$. amphitrite CRS due to temperature and the proteinaceous nature of barnacle adhesive, we can use proteomics to investigate possible explanations for this correlation. Proteomic explorations of barnacle cement have been conducted yet with no relation to environmental factors or tenacity.

Separation and purification of barnacle cement proteins has been difficult due to their insoluble nature within cured cement. Proteins from Megabalanus rosa secondary cement were broken down into fractions based on their chemical solubility (or insolubility) by Kamino et al. (1996). The cement amino acid composition while attached to a substrate (primary cement) has shown to be similar to the secondary cement produced once a barnacle is released from the substratum (Naldrett and Kaplan 1997).

Using reverse phase high-performance liquid chromatography (RP-HPLC) Kamino et al. (1996) were able to determine the amino acid profile as well as complete CB-peptide separations with 1D SDS PAGE for only the soluble fractions ( $50 \%$ of cement contents). In later studies (Kamino 2000) over $90 \%$ of the cement was rendered soluble with the addition of $6 \mathrm{M}$ guanidine hydrochloride $(\mathrm{Gdn} \mathrm{HCl})$ to the suspension buffer and by reducing with dithiothreitol (DTT). Basically they concluded that the complex network of cement proteins are extremely difficult though possible to identify and are responsible for underwater adhesion.

An old method of cement collection (Cheung et al. 1977) has inspired recent studies of barnacle adhesive (Dickinson et al. 2009). By extracting the cement as it is 
produced in liquid form, solubilizing the proteins becomes much easier. Here, liquid cement collection was employed in attempt to analyze cement protein content using 2D SDS PAGE followed by Mass Spectrometry (MALDI/TOFTOF). Only one dimensional SDS PAGE has been conducted on adhesive proteins in previous research (Kamino et al. 1996; Naldrett and Kaplan 1997; Kamino et al. 2000; Kamino 2001; Mori et al. 2007). By further separating proteins across isoelectric charge using, we hoped to improve knowledge of barnacle cement expression. If significant differences in protein expression are discovered within cement collected from barnacles reared under different temperatures, these proteins may be attributed to cement tenacity.

\subsection{Materials and Methods}

3.2.1 Larval settlement and barnacle rearing

Barnacle larvae were received and settled as described in section 2.2.1.2 on February 22 , 2008. However, barnacles were raised within $15^{\circ} \mathrm{C}$ and $25^{\circ} \mathrm{C}$ only. Barnacles were fed as described previously; their diet was shifted to Artemia sp. 19 days after settlement.

\subsubsection{Cement collection}

On August 1, 2008 barnacles were removed from T2 slides using a scalpel. Only barnacles with completely intact basal and side plates were used. After removal, barnacles were carefully cleaned of algae and salt residue using a sterile Q-tip dipped in 
DI water. They were then placed on Kimwipes $@$ and allowed to dry for no longer than one hour.

To remove cement, a sharp probe was used to gently pick at the cement channel openings along the basal/side plate junction. Viable barnacles produced a droplet of uncured cement at the newly opened channel (Figure 17). This droplet was quickly collected into a $20 \mu 1$ pipette tip and immediately placed into rehydration buffer (described below). Due to the difficulty of this protein collection method, as described by recent fouling research (Rittschof et al. 2008; Dickinson et al. 2009), samples from one to three barnacles were pooled giving a maximum of $5 \mu 1$ and minimum of $3 \mu 1$ cement volume per gel. I collected cement from barnacles from both temperature treatments to create four replicates within each treatment. It was important to work quickly throughout this process so the liquid cement did not cure before being placed into the buffer and barnacles did not dry out before being sampled.

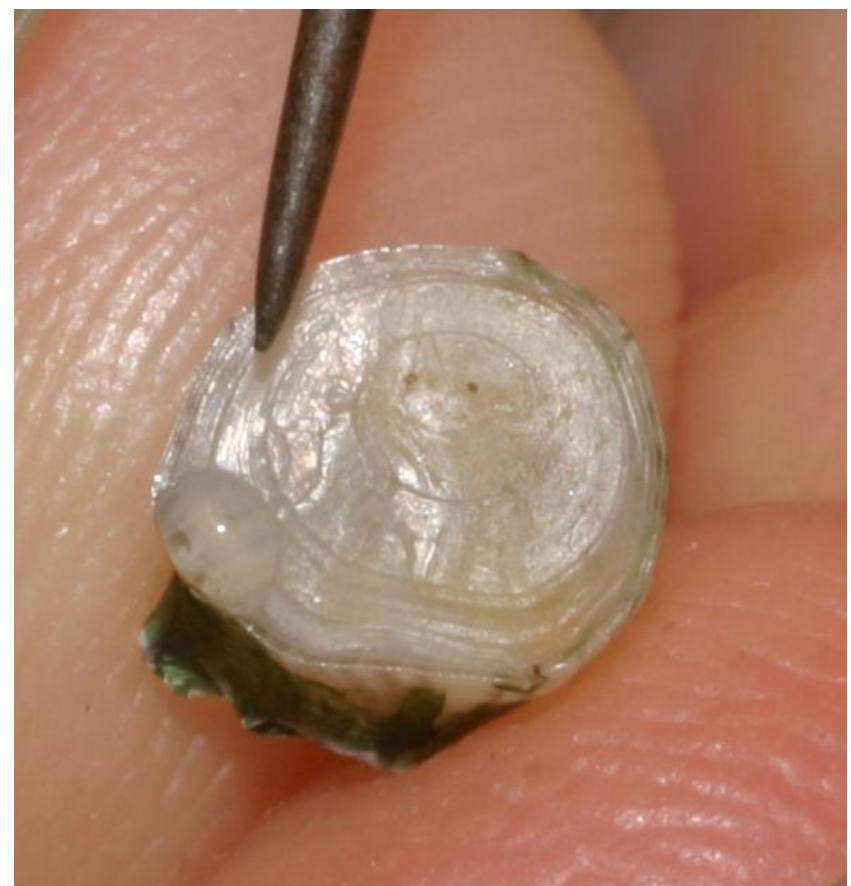

Figure 17. A droplet of liquid cement has formed on a barnacle basis after probing the cement channel. 


\subsubsection{Protein purification and concentration analysis}

We were not able to get exact protein concentrations for samples used in the 2D gels because it is not possible to collect enough cement from each barnacle. Instead, a protein concentration assay was used as an estimate on which to base the buffer recipes. Approximately $4.5 \mu 1$ uncured-cement was collected and placed into $90 \mu 1$ sample buffer (3-10 pH). Standards were made using Bovine Syrum Albumin (BSA) in accordance to 2D Quant Kit instructions (Amersham).

\subsubsection{Isoelectric Focusing and Protein Separation}

IPG Rehydration buffer was created using instructions given by Amersham to create $25 \mathrm{~mL}$ buffer (10.6g Urea, $3.8 \mathrm{~g}$ Thiourea, $0.5 \mathrm{~mL}$ Nanidet P-40, $0.5 \mathrm{~g}$ CHAPS, and $0.125 \mathrm{~mL} 1 \%$ Bromophenol Blue). Protein samples were added directly into $200 \mu 1$ working buffer. Eight $11 \mathrm{~cm} \mathrm{IPG} \mathrm{Ready} \mathrm{Strips} \mathrm{(BioRad)} \mathrm{pH} \mathrm{3-10} \mathrm{were} \mathrm{covered} \mathrm{with} \mathrm{the}$ protein/buffer solution and allowed to passively rehydrate for 12 hours. IPG strips were subject to isoelectric focusing in an Ettan IPGphor3 (GE Healthcare). Focusing was performed as follows according to Tomanek Protocol 2: S1 $=500 \mathrm{~V}$ for $1 \mathrm{~h}, \mathrm{~S} 2=1000 \mathrm{~V}$ for $1 \mathrm{~h}, \mathrm{~S} 3=6000 \mathrm{~V}$ for $2.5 \mathrm{~h}, \mathrm{~S} 4=6000$ for $1.5 \mathrm{~h}$, and $\mathrm{S} 5=500 \mathrm{~V}$ for $17.5 \mathrm{~h}$.

Gel strips were equilibrated with $1.6 \mathrm{~mL}$ per strip of Equilibration Buffer 1 (EBI) (375 M Tris (pH 8.8), 6M Urea, 30\% Glycerol, 2\% SDS and 1\% (w/v) DTT) and allowed to sit on a rotating table for 15 minutes. The solution was discarded and each strip was covered with $1.6 \mathrm{~mL}$ of EBII (same as EBI but including $2.5 \%$ Iodoacidimide (to reduce 
possible disulphide bridges between cysteine residues) instead of DTT) and allowed to rotate for another 15 minutes.

Each IPG strip was placed across precast $10-20 \%$ polyacrylamide Ready Gels (BioRad). A layer of $0.8 \%$ Agarose containing Bromophenol Blue was added on top of the strips and $7.5 \mu 1$ of low-range standard was added to each well. The gels were placed into a Criterion Dodeca Cell and were run at 200V for 112 minutes.

\subsubsection{Gel imaging and analysis}

Sypro Ruby fluorescent stain (Invitrogen) was used to stain gel-imbedded proteins in a 1:1 concentration. Gels were kept in a cardboard box to minimize exposure to light and remained in stain for approximately 20 hours on a rotating table. A 50\% methanol/10\% acetic acid fix solution was used to fix stain in two 30 minute sessions. Gels were then washed twice in a $10 \%$ methanol / $7 \%$ acetic acid solution.

Gel images were collected with a Typhoon Trio variable mode imager (Amersham Biosciences). Using the software program Delta 2D 4.0 (Decodon) gel images were warped to ensure accurate spot matching between gels. A t-test was performed to compare protein spots (protein expression) between samples from $15^{\circ} \mathrm{C}$ and $25^{\circ} \mathrm{C}$. The analysis used raw, normal data assuming equal group variance with a critical value of 0.05 . Hierarchical clusters were created using Pearson's correlation.

\subsubsection{Spot picking and preparation}

I chose prominent spots from a particularly clean gel within each temperature treatment $\left(11\right.$ spots from $25^{\circ} \mathrm{C}$ and 19 spots from $\left.15^{\circ} \mathrm{C}\right)$ as well as two blank spots in 
each (Figure 18). Protein spots were removed from gels using a Proteome Works Spot Cutter (BioRad). Protein was purified with Trypsin In Gel Digest protocol using Anchorchip $^{\mathrm{TM}}$ Technology as modified by Lauren Hitt 2008. A $0.2 \mathrm{mg} / \mathrm{mL}$ alphahydroxycyanocinnamic acid (HCCA) Matrix was mixed in with each sample in the 90well plate. Digestion was carried out overnight at $37^{\circ} \mathrm{C}$. The peptides were extracted from the gel using a 2:1 triflouroacetic acid / acetonitrile solution and the matrix recrystalized with $0.5 \mu$ recrystalization buffer $(\mathrm{EtOH}$, Acetone, $0.1 \% \mathrm{TFA}$ in a 6:3:1 ratio, respectively) added to each sample. 

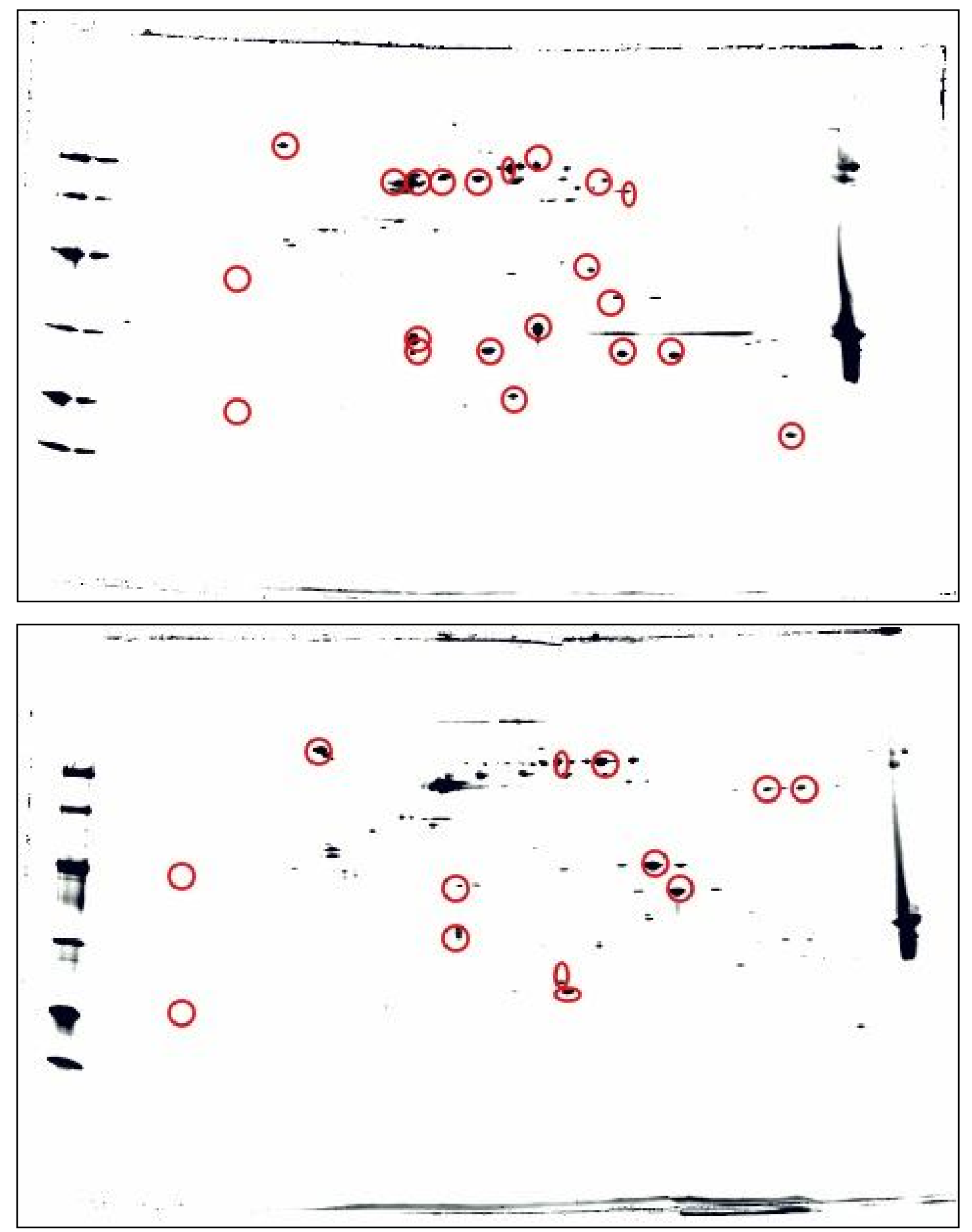

Figure 18. Gels containing proteins from (bottom) with spots cut for Mass Spec $25^{\circ} \mathrm{C}$ treatment (top) and $15^{\circ} \mathrm{C}$ treatment analysis circled in red. 


\subsubsection{MASS Spectrometry}

MALDI TOF-TOF protein fragmentation was performed with a Peptide Calibration Standard II mono (Bruker, 206195) along with the MS peptide mass fingerprinting (PMF) protocol. Intensity was shifted to $30 \%$ for internal calibration with Trypsin Promega Porcine. Mass tolerance level was set to 100ppm. MOWSE scores were determined with Mascot MS/MS search engine (Matrix Science) against the Crustacea protein database from the National Center for Biotechnology Information (NCBI). Balanus amphitrite genome has not yet been sequenced, therefore we could only search within a broad category for possible amino acid sequence matches. The Mascot score is estimated by the negative logarithm of the probability that a match between experimental peptide and database peptide is a random event; a higher score indicates a lower probability that the match was random. Lifts were conducted on eight protein targets that showed promising scores in order to obtain peptide peaks with higher sensitivity.

\subsection{Results}

\subsubsection{Protein concentration in cement}

The estimated protein concentration in B. amphitrite cement is $21.27 \mu \mathrm{g}$ protein for every $1 \mu 1$ uncured cement. 


\subsubsection{Gel image analysis}

Approximately 400 total spots were detected by Delta 2D in the fused image. The t-test using a 0.05 confidence value deemed 40 significantly different spots (10\%) between the two treatments (Figure 19). Within the $15^{\circ} \mathrm{C}$ treatment, 16 protein spots had a significantly higher expression level than in the $25^{\circ} \mathrm{C}$ treatment. Figure 20 illustrates a hierarchical tree of significantly different spots between temperature treatments. Each square in the figure is associated with a significant spot. The red column on the right of the tree represents the spots that had higher expression levels within the $25^{\circ} \mathrm{C}$ treatment compared to the $15^{\circ} \mathrm{C}$ treatment and the blue column is representing higher expression within $15^{\circ} \mathrm{C}$. 

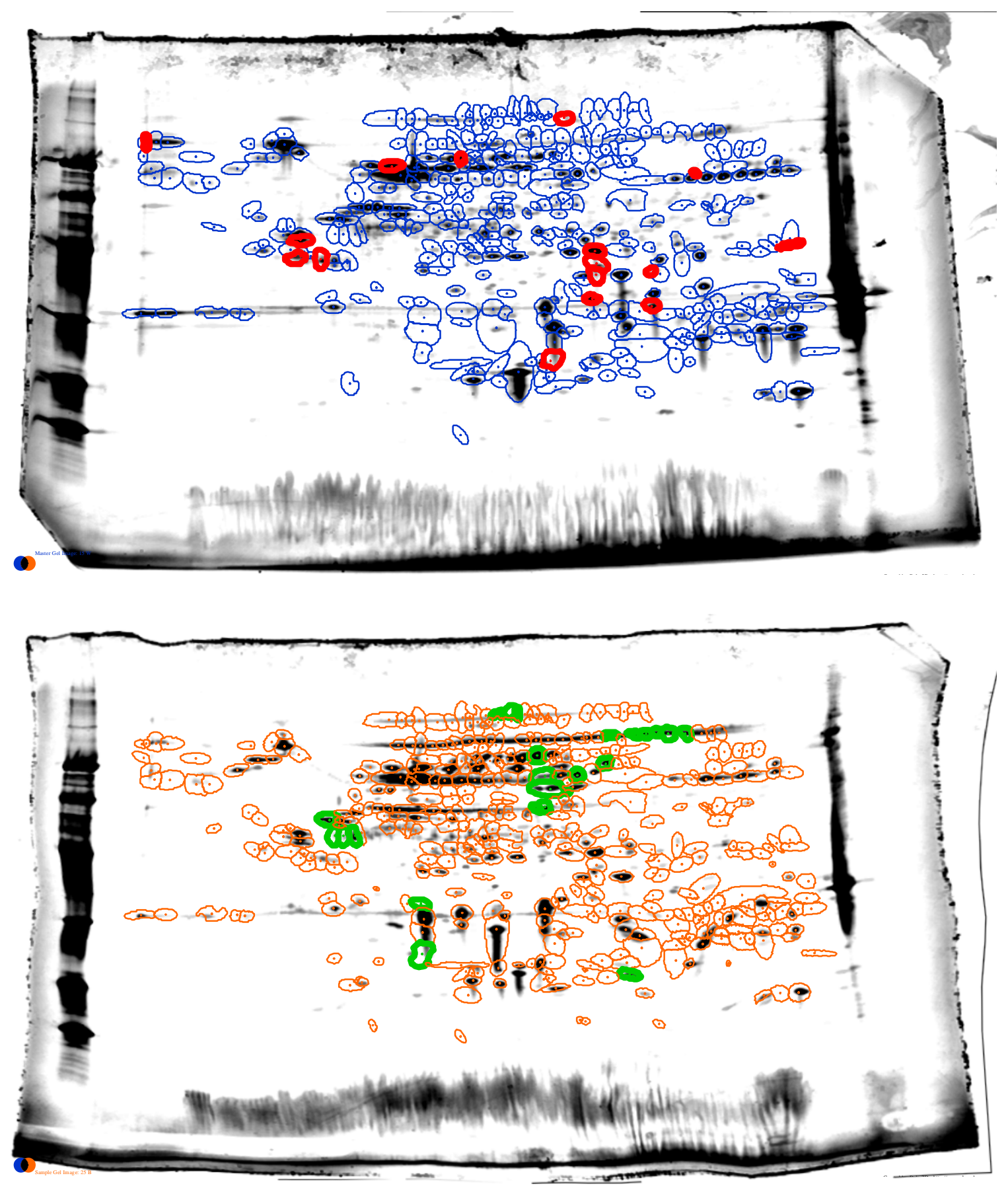

Figure 19. Example gels from temperature treatments with all identified spots circled (top: $15^{\circ} \mathrm{C}$, bottom: $25^{\circ} \mathrm{C}$ ). Proteins with significantly higher expression levels are highlighted in their respective treatment. 


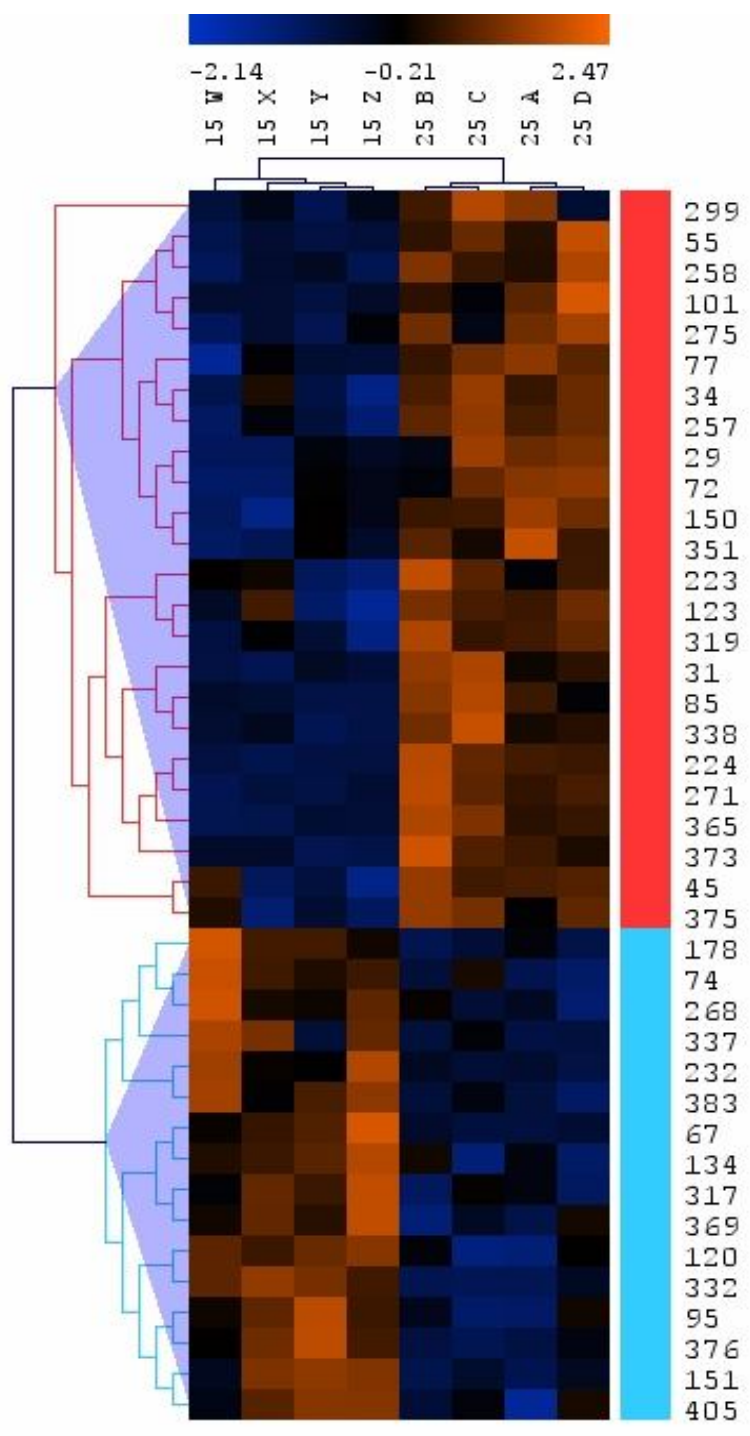

Figure 20. Hierarchical tree of significantly different spots between treatments. Clusters are based on t-test with p-value of 0.05 . Blue bar represents those spots that had a higher expression within the $15^{\circ} \mathrm{C}$ treatment than the $25^{\circ} \mathrm{C}$ treatment (red bar is vise versa).

\subsubsection{MASS spectrometry analysis}

Gel cores were subjected to in-gel trypsin digestion and the resulting peptide mixture was analyzed with MS/MS spectrometry. None of the polypeptides had a Mowse score higher than the significant value 19 , thus proteins were not able to be identified. 


\subsection{Discussion}

Of the 400 spots detected by $2 \mathrm{D}$ gel electrophoresis, 30 spots were selected for analysis by MASS spectrometry. These were selected because they were significantly differentiated between the two temperature treatments and had the highest visual expression. We were unable to identify any of the polypeptides in my samples due to the lack of genomic information on barnacles. In the current database (NCBI) only 22 proteins have been identified for $B$. amphitrite including five G-protein coupled receptors, a 70kDa heat-shock protein and a settlement inducing protein complex. This amount of genomic information was not sufficient to make comparisons to my samples.

The protein contents of barnacle cement has been the topic of considerable research as of late (Kamino 2001; Mori et al. 2007; Urushida et al. 2007; Kamino 2008; Dickinson et al. 2009) yet few cement proteins have been added to the database (19kDa, $20 \mathrm{kDa}$, and $100 \mathrm{kDa}$ as well as insoluble partial peptide fractions). Although many were collected from a different, though similar species, Megabalanus rosa, we were consequently hopeful in identifying similar cement polymers on the basis that partial sequence data may be used.

This preliminary proteomics work on Balanus amphitrite was successful in obtaining clear 2D SDS PAGE gel images which were effectively analyzed. Previous experiments of this nature had difficulty solubilizing cement proteins due to the extraction method of the cement. These studies collected cement that had already been cured on the barnacle basal plate or substrate. Our method of obtaining and utilizing the cement in an uncured liquid form proved to be much easier and just as lucrative in obtaining results. This coincides with Naldrett et al. (1997) who noted that barnacle 
cements are more simply analyzed in their most hydrated state than when allowed to dry. Additionally, we can be confident this method is accurate because the secondary cement produced after the basal channel has been opened is identical to the primary cement present while the barnacle is attached to the substratum (Kamino 1996).

The following are suggestions for future research with B. amphitrite physiology and cement composition. This is the most widely used barnacle species for foul-release coating performance testing. With an increased knowledge of this species' adhesion ability, coating testing will become more effective in providing materials scientists with useful information.

Differences were found between the two temperature treatments and may be correlated to differences in adhesive ability of barnacle cement. An increase in smaller matrix proteins within mucus has shown to increase viscosity or shear stress of the fluid (Pawlicki 2004). Eighteen spots in the $15^{\circ} \mathrm{C}$ treatment had a higher expression level in comparison to the $25^{\circ} \mathrm{C}$ treatment. The size of these highly expressed proteins were evenly spread throughout the size spectrum (between 97 and $15 \mathrm{kDa}$ ) and were not identifiable by a particular size class. The goal of this study was to identify specific proteins responsible for the increase in shear removal stress seen in living barnacles reared at $15^{\circ} \mathrm{C}$. It remains unknown what the functions of these temperature sensitive proteins are. It may still be possible, however to obtain protein identifications through other research methods described below. Increasingly comprehensive databases, as more genomes are sequenced, will aid subsequent research on barnacle cement proteins.

Future research is suggested to improve upon these results. Prior studies (Kamino 1996, 2000, 2001; Naldrett 1997; Urushida 2007) have described methods used in 
identifying barnacle cement protein amino acid composition and specific protein sequences. The most recent of these methods such as bacterial recombination will be valuable in characterizing the cement proteins of $B$. amphitrite. A new method of uncured cement collection described herein greatly improves the ease at which cement proteins are solubilized. With this method, harsh chemicals such as $\mathrm{GdnHCl}$ and high concentrations of formic acid are unnecessary and the entire sample homogenization step is removed from the SDS PAGE process.

Initial data are needed from $B$. amphitrite cement before protein identification with MS/MS will become useful. These data include amino acid concentrations, $\mathrm{N}$ terminal amino sequences and cDNA clone sequencing. Even so, it is unlikely that Mass Spec research on barnacles will prove lucrative until a much larger percentage of the genome has been sequenced.

Techniques following previous research on barnacle cement may give needed insight into B. amphitrite cement composition. Naldrett et al. (1997) were able to crudely characterize proteins and their amino acid composition from the barnacles Balanus eburneus $(7,22,36,52$, and $58 \mathrm{kDa})$ and Balanus crenatus (many bands between 3-50 $\mathrm{kDa}$ ) using 1D SDS PAGE and gas-phase hydrolysis and the $\mathrm{N}$ terminal was sequenced using Model P12090 gas-phase sequencer. Kamino et al. (2000) created a cDNA clone of a major cement protein, which was isolated and site specific expression of the gene was completed after insertion into $p \mathrm{UC} 19$ with Prism dye terminator cycle sequencing kit and 373 DNA sequencer. The amino acid composition of this protein was determined using TOSOH automatic amino acid analyzer using a 4-flouro-7 nitrobenofurazan for detection and RP HPLC for separation. 
A particularly interesting study was conducted by Urushida et al. (2007) in which a novel $19 \mathrm{kDa}$ cement protein was discovered to be expressed only in the basal portion of the barnacle, $M$. rosa, where the cement glands are located. Using bacterial recombination, the protein demonstrated underwater, irreversible adsorption to a variety of substrata. Homologous genes were identified in two Balanus sp. where amino acid composition strongly resembled that of $M$. rosa. If a homologue of this nature is found in B. amphtrite, scientists continuing with this research would be able to manufacture cement for foul-release coating performance assays and use pseudobarnacles rather than living animals. Often, healthy cyprid availability is variable and dependent on one source (DUML). By removing the time and money used to rear barnacles, not to mention the time wasted when cyprids do not survive or metamorphose, work-flow could increase significantly.

This research has brought to light how a model organism in the laboratory may not translate to a model system for proteomics research. This integrative approach to studying antifouling technologies is imperative to understanding the complete interaction between fouling organism and antifouling or foul-release coating. Although so much work has yet to be done, studies such as this as well as those described above have elucidated the direction this research should head. In a global climate that is changing at an unparalleled rate due to anthropogenic effects, every step possible taken to reduce these negative effects is a necessary one. Removing biofouling in a way that decreases marine species invasions, does not cause biocide accumulation and allows for sufficient movement of boats through the water, thus reducing fuel consumption, is a step towards reducing our negative impact on the Earth. 


\section{Bibliography}

Abarzua, S \& Jakubowski, S. 1995. Biotechnological investigation for the prevention of biofouling .1. Biological and biochemical principles for the prevention of biofouling. Marine Ecology-Progress Series. 123: 301-312.

Alzieu, C. 2000. Impact of tributyltin on marine invertebrates. Ecotoxicology. 9: 71-76.

Anderson, C, Atlar, M, Callow, M, Candries, M, Milne, A \& Townsin, R L. 2003. The development of foul-release coatings for seagoing vessels. Proceedings of IMarEST Part B - Journal of Marine Design and Operations. 2003: 11-23.

Anil, A C, Chiba, K, Okamoto, K \& Kurokura, H. 1995. Influence of temperature and salinity on larval development of balanus amphitrite - implications in fouling ecology. Marine Ecology-Progress Series. 118: 159-166.

Anil, A C, Desai, D \& Khandeparker, L. 2001. Larval development and metamorphosis in balanus amphitrite darwin (cirripedia; thoracica): Significance of food concentration, temperature and nucleic acids. Journal of Experimental Marine Biology and Ecology. 263: $125-141$.

Berger, M S \& Emlet, R B. 2007. Heat-shock response of the upper intertidal barnacle balanus glandula: Thermal stress and acclimation. Biological Bulletin. 212: 232-241.

Berglin, M \& Gatenholm, P. 1999. The nature of bioadhesive bonding between barnacles and fouling-release silicone coatings. Journal of Adhesion Science and Technology. 13: 713-727.

Berglin, M \& Gatenholm, P. 2003. The barnacle adhesive plaque: Morphological and chemical differences as a response to substrate properties. Colloids and Surfaces BBiointerfaces. 28: 107-117.

Berglin, M, Larsson, A, Jonsson, P R \& Gatenholm, P. 2001. The adhesion of the barnacle, balanus improvisus, to poly(dimethylsiloxane) fouling-release coatings and poly(methyl methacrylate) panels: The effect of barnacle size on strength and failure mode. Journal of Adhesion Science and Technology. 15: 1485-1502.

Berglin, M, Lonn, N \& Gatenholm, P. 2003. Coating modulus and barnacle bioadhesion. Biofouling. 19: 63-69.

Bourget, E. 1980. Barnacle shell growth and its relationship to environmental factors. Topics in Geobiology. 469-491.

Brady, R F \& Aronson, C L. 2003. Elastomeric fluorinated polyurethane coatings for nontoxic fouling control. Biofouling: The Journal of Bioadhesion and Biofilm Research. 19: $59-62$. 
Brady, R F \& Singer, I L. 2000. Mechanical factors favoring release from fouling release coatings. Biofouling. 15: 73-81.

Brancato, M S \& MacLellan, D. 1999. Impacts of invasive species introduced through the shipping industry. Oceans '99. MTS/IEEE. Riding the Crest into the 21st Century. Conference and Exhibition. Conference Proceedings (IEEE Cat. No.99CH37008)|Oceans '99. MTS/IEEE. Riding the Crest into the 21st Century. Conference and Exhibition. Conference Proceedings (IEEE Cat. No.99CH37008). 676 vol.2|3 vol. xxxiv+1602.

Burnell, T B, Carpenter, J C, Carroll, K M, Serth-Guzzo, J, Stein, J \& Truby, K E. 1998. Advances in nontoxic silicone biofouling release coatings. Abstracts of Papers of the American Chemical Society. 215: 312-POLY.

Callow, J A, Callow, M E, Ista, L K, Lopez, G \& Chaudhury, M K. 2005. The influence of surface energy on the wetting behaviour of the spore adhesive of the marine alga ulva linza (synonym enteromorpha linza). Journal of the Royal Society Interface. 2: 319-325.

Callow, M \& Callow, J. 2002. Marine biofouling: A sticky problem. Biologist (London). 49: 10-14.

Callow, M E, Callow, J A \& Wendt, D E 2007. 91-107. Laboratory methods to access the antifouling and foul-release properties of novel, non-biocidal marine coatings. New developments in coatings technology. Washington, DC: American Chemical Society.

Chaudhury, M K, Finlay, J A, Chung, J Y, Callow, M E \& Callow, J A. 2005. The influence of elastic modulus and thickness on the release of the soft-fouling green alga ulva linza (syn. Enteromorpha linza) from poly(dimethylsiloxane) (pdms) model networks. Biofouling. 21: 41-48.

Cheung, P J, Ruggieri, G D \& Nigrelli, R F. 1977. New method for obtaining barnacle cement in liquid-state for polymerization studies. Marine Biology. 43: 157-163.

Clare, A, Thomas, R \& Rittschof, D. 1995. Evidence for the involvement of cyclic amp in the pheromonal modulation of barnacle settlement. J Exp Biol. 198: 655-664.

Clare, A S \& Matsumura, K. 2000. Nature and perception of barnacle settlement pheromones. Biofouling: The Journal of Bioadhesion and Biofilm Research. 15: 57 - 71.

Cleary, J J \& Stebbing, A R D. 1985. Organotin and total tin in coastal waters of southwest england uk. Marine Pollution Bulletin. 16: 350-355.

Clegg, J S, Uhlinger, K R, Jackson, S A, Cherr, G N, Rifkin, E \& Friedman, C S. 1998. Induced thermotolerance and the heat shock protein-70 family in the pacific oyster crassostrea gigas. Molecular Marine Biology and Biotechnology. 7: 21-30.

Conlan, S L, Mutton, R J, Aldred, N \& Clare, A S. 2008. Evaluation of a fully automated method to measure the critical removal stress of adult barnacles. Biofouling. 24: 471-81. 
Crisp, D J. 1983. Extending darwin investigations on the barnacle life-history. Biological Journal of the Linnean Society. 20: 73-83.

Crisp, D J. 1985. Recruitment of barnacle larvae from the plankton. Bulletin of Marine Science. 37: 478-486.

Crisp, D J. 1990. Gregariousness and systematic affinity in some north-carolinian barnacles. Bulletin of Marine Science. 47: 516-525.

Crisp, D J \& Bourget, E. 1985. Growth in barnacles. Advances in Marine Biology. 22: 199-244.

Crisp, D J, Walker, G, Young, G A \& Yule, A B. 1985. Adhesion and substrate choice in mussels and barnacles. Journal of Colloid and Interface Science. 104: 40-50.

Dahlstrom, M, Jonsson, H, Jonsson, P R \& Elwing, H. 2004. Surface wettability as a determinant in the settlement of the barnacle balanus improvisus (darwin). Journal of Experimental Marine Biology and Ecology. 305: 223-232.

Darwin, C. 1851. A monograph on the sub-class cirripedia. I. The lepadidae. Ray Society, London, i-xi. 1-400.

Desai, D V \& Anil, A C. 2004. The impact of food type, temperature and starvation on larval development of balanus amphitrite darwin (cirripedia : Thoracica). Journal of Experimental Marine Biology and Ecology. 306: 113-137.

Desai, D V, Anil, A C \& Venkat, K. 2006. Reproduction in balanus amphitrite darwin (cirripedia : Thoracica): Influence of temperature and food concentration. Marine Biology. 149: 1431-1441.

Dickinson, G H, Vega, I E, Wahl, K J, Orihuela, B, Beyley, V, Rodriguez, E N, Everett, R K, Bonaventura, J \& Rittschof, D. 2009. Barnacle cement: A polymerization model based on evolutionary concepts. Journal of Experimental Biology. 212: 3499-3510.

Faimali, M, Garaventa, F, Terlizzi, A, Chiantore, M \& Cattaneo-Vietti, R. 2004. The interplay of substrate nature and biofilm formation in regulating balanus amphitrite darwin, 1854 larval settlement. Journal of Experimental Marine Biology and Ecology. 306: $37-50$.

Glenner, H \& Hoeg, J T. 1993. Scanning electron-microscopy of metamorphosis in 4 species of barnacles (cirripedia-thoracica balanomorpha). Marine Biology. 117: 431-439.

Godwin, L S, Eldredge, L G \& Gaut, K. 2004. The assessment of hull fouling as a mechanism for the introduction and dispersal of marine alien species in the main hawaiian islands. Bishop Museum Technical Report. 28: i-iv, 1-113. 
Hills, J M, Thomason, J C, Milligan, J L \& Richardson, T. 1998. Do barnacle larvae respond to multiple settlement cues over a range of spatial scales? Hydrobiologia. 376: 101-111.

Hoipkemeier-Wilson, L, Schumacher, J, Carman, M, Gibson, A, Feinberg, A, Callow, M, Finlay, J, Callow, J \& Brennan, A. 2004. Antifouling potential of lubricious, microengineered, pdms elastomers against zoospores of the green fouling alga ulva (enteromorpha). Biofouling. 20: 53-63.

Holm, E, Orihuela, B, Kavanagh, C J \& Rittschof, D. 2005. Variation among families for characteristics of the adhesive plaque in the barnacle balanus amphitrite. Biofouling. 21: 121-126.

Holm, E, Schultz, M, Haslbeck, E, Talbott, W \& Field, A. 2004a. Evaluation of hydrodynamic drag on experimental fouling-release surfaces, using rotating disks. Biofouling. 20: 219 - 226.

Holm, E R. 1990. Attachment behavior in the barnacle balanus-amphitrite amphitrite (darwin) - genetic and environmental-effects. Journal of Experimental Marine Biology and Ecology. 135: 85-98.

Holm, E R, Kavanagh, C J, Meyer, A E, Wiebe, D, Nedved, B T, Wendt, D, Smith, C M, Hadfield, M G, Swain, G, Wood, C D, Truby, K, Stein, J \& Montemarano, J. 2006. Interspecific variation in patterns of adhesion of marine fouling to silicone surfaces. Biofouling. 22: 233-243.

Holm, E R, McClary, M \& Rittschof, D. 2000. Variation in attachment of the barnacle balanus amphitrite: Sensation or something else? Marine Ecology-Progress Series. 202: 153-162.

Holm, E R, Orihuela, B \& Rittschof, D. 2004b. Genetic variation in adhesive tenacity and adhesive plaque characteristics in the barnacle balanus amphitrite. Integrative and Comparative Biology. 44: 570-570.

Kamino, K. 2001. Novel barnacle underwater adhesive protein is a charged amino acidrich protein constituted by a cys-rich repetitive sequence. Biochemical Journal. 356: 503507.

Kamino, K. 2008. Underwater adhesive of marine organisms as the vital link between biological science and material science. Marine Biotechnology. 10: 111-121.

Kamino, K, Inoue, K, Maruyama, T, Takamatsu, N, Harayama, S \& Shizuri, Y. 2000. Barnacle cement proteins - importance of disulfide bonds in their insolubility. Journal of Biological Chemistry. 275: 27360-27365.

Kamino, K, Odo, S \& Maruyama, T. 1996. Cement proteins of the acorn barnacle, megabalanus rosa. Biological Bulletin. 190: 403-409. 
Kavanagh, C J, Quinn, R D \& Swain, G W. 2005. Observations of barnacle detachment from silicones using high-speed video. Journal of Adhesion. 81: 843-+.

Kavanagh, C J, Schultz, M P, Swain, G W, Stein, J, Truby, K \& Wood, C D. 2001. Variation in adhesion strength of balanus eburneus, crassostrea virginica and hydroides dianthus to fouling-release coatings. Biofouling. 17: 155-167.

Kawahara, H, Tamura, R, Ajioka, S \& Shizuri, Y. 1999. Convenient assay for settlement inducing substances of barnacles. Marine Biotechnology. 1: 98-101.

Khandeparker, L \& Anil, A C. 2007. Underwater adhesion: The barnacle way. International Journal of Adhesion and Adhesives. 27: 165-172.

Khandeparker, L, Anil, A C \& Raghukumar, S. 2002. Factors regulating the production of different inducers in pseudomonas aeruginosa with reference to larval metamorphosis in balanus amphitrite. Aquatic Microbial Ecology. 28: 37-54.

Knight-Jones, E W. 1953. Laboratory experiments on gregariousness during setting in balanus balanoides and other barnacles. J Exp Biol. 30: 584-598.

Konya, K \& Miki, W. 1994. Effects of environmental-factors on larval settlement of the barnacle balanus-amphitrite reared in the laboratory. Fisheries Science. 60: 563-565.

Lau, S C K, Thiyagarajan, V, Cheung, S C K \& Qian, P Y. 2005. Roles of bacterial community composition in biofilms as a mediator for larval settlement of three marine invertebrates. Aquatic Microbial Ecology. 38: 41-51.

Li, N K \& Denny, M W. 2004. Limits to phenotypic plasticity: Flow effects on barnacle feeding appendages. Biological Bulletin. 206: 121-124.

Maki, J S, Rittschof, D \& Mitchell, R. 1992. Inhibition of larval barnacle attachment to bacterial films: An investigation of physical properties. Microbial Ecology. 23: 97-106.

Marchinko, K B. 2003. Dramatic phenotypic plasticity in barnacle legs (balanus glandula darwin): Magnitude, age dependence, and speed of response. Evolution. 57: 1281-1290.

Matthiessen, P \& Gibbs, P E. 1998. Critical appraisal of the evidence for tributyltinmediated endocrine disruption in mollusks. Environmental Toxicology and Chemistry. 17: 37-43.

Mineur, F, Johnson, M P \& Maggs, C A. 2008. Macroalgal introductions by hull fouling on recreational vessels: Seaweeds and sailors. Environmental Management. 42: 667-676.

Miron, G, Walters, L J, Tremblay, R \& Bourget, E. 2000. Physiological condition and barnacle larval behavior: A preliminary look at the relationship between tag/DNA ratio and larval substratum exploration in balanus amphitrite. Marine Ecology-Progress Series. 198: 303-310. 
Montero, C, Battaglia, B, Stenico, M, Campesan, G \& Patarnello, T. 1994. Effects of heavy-metals and temperature on the genetic-structure and gpi enzyme-activity of the barnacle balanus-amphitrite darwin (cirripedia, thoracica). Genetics and Evolution of Aquatic Organisms. 447-459.

Mori, Y, Urushida, Y, Nakano, M, Uchiyama, S \& Kamino, K. 2007. Calcite-specific coupling protein in barnacle underwater cement. Febs Journal. 274: 6436-6446.

Mullineaux, L S \& Butman, C A. 1991. Initial contact, exploration and attachment of barnacle (balanus amphitrite) cyprids settling in flow. Marine Biology. 110: 93-103.

Naldrett, M J \& Kaplan, D L. 1997. Characterization of barnacle (balanus eburneus and b-cenatus) adhesive proteins. Marine Biology. 127: 629-635.

Odling, K, Albertsson, C, Russell, J T \& Martensson, L G E. 2006. An in vivo study of exocytosis of cement proteins from barnacle balanus improvisus (d.) cyprid larva. Journal of Experimental Biology. 209: 956-964.

Parsell, D A, Taulien, J, Lindquist, S, Viitanen, P, Jaenicke, R, Horwich, A, Hartl, F U, Ellis, R J \& Welch, W J. 1993. The role of heat-shock proteins in thermotolerance [and discussion]. Philosophical Transactions: Biological Sciences. 339: 279-286.

Pawlicki, J M, Pease, L B, Pierce, C M, Startz, T P, Zhang, Y \& Smith, A M. 2004. The effect of molluscan glue proteins on gel mechanics. Journal of Experimental Biology. 207: 1127-1135.

Pechenik, J A, Wendt, D E \& Jarrett, J N. 1998. Metamorphosis is not a new beginning. Bioscience. 48: 901-910.

Pineda, J, DiBacco, C \& Starczak, V. 2005. Barnacle larvae in ice: Survival, reproduction, and time to postsettlement metamorphosis. Limnology and Oceanography. 50: $1520-1528$.

Pineda, J \& Lopez, M. 2002. Temperature, stratification and barnacle larval settlement in two californian sites. Continental Shelf Research. 22: 1183-1198.

Piola, R F, Dafforn, K A \& Johnston, E L. 2009. The influence of antifouling practices on marine invasions. Biofouling. 25: 633-644.

Piola, R F \& Johnston, E L. 2006. Differential resistance to extended copper exposure in four introduced bryozoans. Marine Ecology-Progress Series. 311: 103-114.

Piola, R F \& Johnston, E L. 2008. The potential for translocation of marine species via small-scale disruptions to antifouling surfaces. Biofouling. 24: 145-155.

Prosser, C L, David, C F S, Dawson, M, Sabin, T D, Functions, E B \& Kosslyn, N S M. 1991. Environmental and metabolic animal physiology: Comparative animal physiology. Stress. 93602: 2. 
Qiu, J W \& Qian, P Y. 1999. Tolerance of the barnacle balanus amphitrite amphitrite to salinity and temperature stress: Effects of previous experience. Marine Ecology-Progress Series. 188: 123-132.

Ramsay, D B, Dickinson, G H, Orihuela, B, Rittschof, D \& Wahl, K J. 2008. Base plate mechanics of the barnacle balanus amphitrite (=amphibalanus amphitrite). Biofouling. 24: 109-118.

Rittschof, D, Orihuela, B, Stafslien, S, Daniels, J, Christianson, D, Chisholm, B \& Holm, E. 2008. Barnacle reattachment: A tool for studying barnacle adhesion. Biofouling. 24: 19.

Roberts, D, Hofmann, G E \& Somero, G N. 1997. Heat-shock protein expression in mytilus californianus: Acclimatization (seasonal and tidal-height comparisons) and acclimation effects. Biological Bulletin. 192: 309-320.

Roberts, D, Rittschof, D, Holm, E \& Schmidt, A R. 1991. Factors influencing initial larval settlement - temporal, spatial and surface molecular-components. Journal of Experimental Marine Biology and Ecology. 150: 203-221.

Saroyan, J R, Lindner, E, Dooley, C A \& Bleile, H R. 1970. Barmacle cement-key to second generation antifouling coatings. Product R\&D. 9: 122-133.

Schultz, M P. 2007. Effects of coating roughness and biofouling on ship resistance and powering. Biofouling. 23: 331-341.

Schultz, M P, Finlay, J A, Callow, M E \& Callow, J A. 2003. Three models to relate detachment of low form fouling at laboratory and ship scale. Biofouling. 19: 17-26.

Smith, A M, Quick, T J \& Peter, R L S. 1999. Differences in the composition of adhesive and non-adhesive mucus from the limpet lottia limatula. Biological Bulletin. 196: 34-44.

Smith, A M, Startz, T, Rahme, D \& Pierce, C. 2002. Proteins characteristic of the adhesive mucus of molluscs and their potential role in determining gel function. Integrative and Comparative Biology. 42: 1315-1315.

Stebbing, A R D. 1985. Organotins and water-quality - some lessons to be learned. Marine Pollution Bulletin. 16: 383-390.

Stein, J, Truby, K, Wood, C D, Takemori, M, Vallance, M, Swain, G, Kavanagh, C, Kovach, B, Schultz, M, Wiebe, D, Holm, E, Montemarano, J, Wendt, D, Smith, C \& Meyer, A. 2003. Structure-property relationships of silicone biofouling-release coatings: Effect of silicone network architecture on pseudobarnacle attachment strengths. Biofouling. 19: 87-94.

Sun, Y J, Guo, S L, Walker, G C, Kavanagh, C J \& Swain, G W. 2004. Surface elastic modulus of barnacle adhesive and release characteristics from silicone surfaces.

Biofouling. 20: 279-289. 
Swain, G, Anil, A C, Baier, R E, Chia, F S, Conte, E, Cook, A, Hadfield, M, Haslbeck, E, Holm, E, Kavanagh, C, Kohrs, D, Kovach, B, Lee, C, Mazzella, L, Meyer, A E, Qian, P Y, Sawant, S S, Schultz, M, Sigurdsson, J, Smith, C, Soo, L, Terlizzi, A, Wagh, A, Zimmerman, R \& Zupo, V. 2000. Biofouling and barnacle adhesion data for foulingrelease coatings subjected to static immersion at seven marine sites. Biofouling. 16: 331344.

Thiyagarajan, V, Harder, T \& Qian, P Y. 2003. Combined effects of temperature and salinity on larval development and attachment of the subtidal barnacle balanus trigonus darwin. Journal of Experimental Marine Biology and Ecology. 287: 223-236.

Tomanek, L. 2005. Molecular chaperones: Their evolutionary variation, acclimatory plasticity of expression patterns and ecological importance in intertidal snails (genus tegula). Faseb Journal. 19: A673-A673.

Tomanek, L \& Somero, G N. 1999. Evolutionary and acclimation-induced variation in the heat-shock responses of congeneric marine snails (genus tegula) from different thermal habitats: Implications for limits of thermotolerance and biogeography. Journal of Experimental Biology. 202: 2925-2936.

Truby, K, Wood, C, Stein, J, Cella, J, Carpenter, J, Kavanagh, C, Swain, G, Wiebe, D, Lapota, D, Meyer, A, Holm, E, Wendt, D, Smith, C \& Montemarano, J. 2000. Evaluation of the performance enhancement of silicone biofouling-release coatings by oil incorporation. Biofouling. 15: 141-+.

Tunnicliffe, V. 1991. The biology of hydrothermal vents - ecology and evolution. Oceanography and Marine Biology. 29: 319-407.

Urushida, Y, Nakano, M, Matsuda, S, Inoue, N, Kanai, S, Kitamura, N, Nishino, T \& Kamino, K. 2007. Identification and functional characterization of a novel barnacle cement protein. Febs Journal. 274: 4336-4346.

Walker, G. 1971. Study of cement apparatus of cypris larva of barnacle balanusbalanoides. Marine Biology. 9: 205-\&.

Walker, G. 1972. Biochemical composition of cement of 2 barnacle species, balanushameri and balanus-crenatus. Journal of the Marine Biological Association of the United Kingdom. 52: 429-\&.

Watermann, B, Berger, H D, Sonnichsen, H \& Willemsen, P. 1997. Performance and effectiveness of non-stick coatings in seawater. Biofouling. 11: 101-118.

Wendt, D E, Kowalke, G L, Kim, J \& Singer, I L. 2006. Factors that influence elastomeric coating performance: The effect of coating thickness on basal plate morphology, growth and critical removal stress of the barnacle balanus amphitrite. Biofouling. 22: 1-9. 
Wiegemann, M, Kowalik, T \& Hartwig, A. 2006. Noncovalent bonds are key mechanisms for the cohesion of barnacle (balanus crenatus) adhesive proteins. Marine Biology. 149: 241-246.

Wood, C D, Truby, K, Stein, J, Wiebe, D, Holm, E, Wendt, D, Smith, C, Kavanagh, C, Montemarano, J, Swain, G \& Meyer, A. 2000. Temporal and spatial variations in macrofouling of silicone fouling-release coatings. Biofouling. 16: 311-322.

Wright, D A \& Zamuda, C D. 1991. Copper contamination in the patuxent river, maryland. Hydrobiologia. 215: 31-41.

Yule, A B \& Crisp, D J. 1983. Adhesion of cypris larvae of the barnacle, balanusbalanoides, to clean and arthropodin treated surfaces. Journal of the Marine Biological Association of the United Kingdom. 63: 261-271. 